\title{
Access to Medicines to Guarantee Women's Rights to Health in Nigeria
}

\author{
Dr Jennifer Heaven Mike \\ Assistant Professor of Law, School of Law, American University of Nigeria \\ 640101, Yola, Adamawa, Nigeria
}

\begin{abstract}
The state's obligation with regard to the right to health $[\ldots]$ encompasses not only the positive duty to ensure that its citizens have access to health care services and medication but must also encompass the negative duty not to do anything that would in any way affect access to such health care services and essential medicines. Any legislation that would render the cost of essential drugs unaffordable to citizens would thus be in violation of the state's obligations [...]. ${ }^{1}$
\end{abstract}

\begin{abstract}
In making the argument for increased accessibility to health treatments in Nigeria, the article makes the case for women's access through the lens of human rights to health. Human rights principles and norms provide the underlying basis on which this article argues for the enhancement of women's access to medicines in Nigeria. Essentially, human rights provide the jurisprudential justification and legal force in which this study argues for the consideration, interpretation and circumvention of patent rights in favour of increased access to medicines in Nigeria. The article argues that states Nigerian government and relevant authorities have a human rights duty to meet the basic healthcare needs of their people, including ensuring that patent rights do not interfere with the accessibility to medicines. This analysis also aims to examine how human rights can influence the interpretation and enforcement of patents for broader access to medicines. The analysis in this paper is relevant because it demonstrates the constituent reality of the access to medicine phenomenon, and exposes the issues taken for granted in examining the effects of patent rights on medicines on particular vulnerable groups such as women. Thus this article, from a patent standpoint, will focus on the challenges that women face in accessing healthcare and medicines in order to make a case for their increased access, as a means of realising their rights to health in Nigeria.Equally, it is argued that human rights principles can serve as a basis for the resolution of the conflict between private patent rights and public healthcare in favour of health and human welfare where the proprietary rights undermine access to important health treatment. Moreover, human rights norms provide the legal basis for a broader interpretation and implementation of the flexibilities in favour of accessing affordable pharmaceuticals. Keywords: Access to medicines, women, Nigeria, right to health, pharmaceutical patents
\end{abstract}

DOI: $10.7176 / J L P G / 86-05$

Publication date:June $30^{\text {th }} 2019$

\section{Introduction}

This article situates the ongoing debate about pharmaceutical patents, access to medicines and public health within the framework of human rights. The article argues that the exercise and implementation of patent rights can raise human rights issues in the context of human health and access to essential and affordable life-saving pharmaceuticals. More specifically, human rights principles provide a strong moral support and useful framework within which this paper argues for a consideration of women's access to medicines, particularly in Nigeria, in view of the adverse impact of international and national patent law on public health. The article consequently argues for the consideration, interpretation, and implementation of patent rights to respond to the right to health and access to medicines.

This article comprises three sections. The first examines the legal commitment to the rights of women to health in Nigeria. The second part examines the obligation of the Nigerian government to the right to health, particularly, ensuring access to essential medicines. The last part makes a case for women's access to medicines as a basic human right to health, specifically in Nigeria. As Nigeria has committed itself to protect, safeguard and fulfil this right, the study argues that the state has a legal obligation to safeguard the health and wellbeing of everyone, including women, in the context of patent protection and its effect on access to life-saving treatments.

\subsection{Health and the Right to Health}

Good health is one of the many aspects of human wellbeing that is necessary for the enjoyment of human rights. Health, - a person's state of physical and mental condition and wellbeing - also plays a pivotal role in

\footnotetext{
${ }^{1}$ Patricia Asero Ochieng, Maurine Atieno, Joseph Munyi, and AIDS Law Project v Attorney General Petition No. 409 of 2009 (High Court of Kenya) paragraph 66.
} 
empowering people to pursue other activities that will enhance their welfare. ${ }^{1}$ For example, a person who is healthy is in a better position to practically engage in activities he or she find useful, improve their living standards, increase their life chances and also enjoy other human rights. Thus, as an essential state of wellbeing, health is also a means by which people can undertake social, economic and cultural activities as well partake in civil and political activities, and, as a basic human right, health is an essential, fundamental and indispensable state of wellbeing. ${ }^{2}$ In this sense, health is both a human right in itself and an essential means for the realisation of other human rights. ${ }^{3}$ Consequently, the right to health is one of the cornerstones for the enhancement and improvement of overall social, cultural, economic and human development. The right to health, as with all human rights, contains 'freedoms' and 'entitlements. ${ }^{4}$ Freedom includes the right to make decisions and control one's own health and body such as sexual and reproductive rights, while the entitlement aspect of the right to health pertains to the equal rights and opportunity for everyone to access an adequate healthcare system including health services, facilities and drugs. ${ }^{5}$

These guarantees and articulation of human rights to health are acknowledged in several human rights laws and instruments. ${ }^{6}$ The state is obligated to guarantee these rights by respecting, fulfilling and protecting the right from encroachment by third parties such as pharmaceutical companies and other right bearers. Significantly, Nigeria is a signatory to several of these international instruments that establish the right to health, ${ }^{7}$ thus the obligation to fulfil the human right to health may be binding on the government under certain conditions. ${ }^{8}$

\subsubsection{International Legal Commitments to the Right to Health}

The earliest articulation of health as a basic right is in the 1946 Constitution of the World Health organization (WHO) which states that 'the enjoyment of the highest attainable standard of health is one of the fundamental rights of every human being [...]. ${ }^{9}$ This highest standard of physical and mental health as a right of individuals and a duty of the state is also accorded recognition in a number of human rights declarations and treaties. ${ }^{10}$ Implicit in the objective of the UN to 'promote social progress' and 'better standards of life' is the recognition that health is a right worth protecting, and a responsibility of states to recognise, enforce and safeguard in Article 25(1) of the UDHR. ${ }^{11}$ To emphasise the commitment to social security and other socio-economic and cultural rights, including the right to health, Article 22 of the UDHR requires State Parties to expend available resources and take steps individually and through international and national cooperation, to facilitate the realisation of the rights of all citizens to 'economic, social and cultural rights indispensable for his dignity [...]. ${ }^{12}$ The right to health is also acknowledged in other significant human rights frameworks such as Article 5 (e)(iv) of the 1965 International Convention on the Elimination of All Forms of Racial Discrimination; ${ }^{13}$ mentioned in Articles 3, 6,

\footnotetext{
${ }^{1}$ The WHO identified health as a state of complete physical, mental and social well-being and not merely the absence of disease or infirmity. ${ }^{2}$ Michael DA Freeman, Lloyd's Introduction to Jurisprudence (9th edn, Sweet \& Maxwell 2014) 1294.

${ }^{3}$ See Article 1, UN Committee on Economic, Social and Cultural Rights (CESCR), General Comment No 14: The Right to the Highest Attainable Standard of Health (Article 12 of the Covenant) (Adopted at the Twenty-second Session of the Committee on Economic, Social and Cultural Rights, on 11 August 2000 E/C.12/2000/4)

${ }^{4}$ Office of the United Nations High Commissioner for Human Rights and World Health Organization, The Right to Health: Fact Sheet No. 31 (Office of the United Nations High Commissioner for Human Rights and World Health Organization) 3.

Freedoms include: the right to make decisions and control one's own health and body which includes sexual and reproductive rights. 5 ibid

${ }^{6}$ The convergence of these human rights laws indicates that every human being has a fundamental claim to the protection and enjoyment of their rights to an adequate state of health

${ }^{7}$ Nigeria is a signatory to, and has ratified, several human rights international instruments such as the International Covenant on Civil and Political Rights (ICCPR), Ratified October, 29 1993; The International Covenant on Economic, Social and Cultural Rights (ICESCR), Ratified October 29, 1993. The International Convention on the Elimination of All Forms of Racial Discrimination (the ICERD) Ratified January 4, 1969; The Convention Against Torture and Other Cruel, Inhuman or Degrading Treatment or Punishment (CAT) Ratified July 28, 2001; The Convention on the Elimination of All Forms of Discrimination Against Women (CEDAW) Ratified July 13, 1985; and the Convention on the Rights of the Child (CRC) Ratified April 19, 1991. Nigeria has also signed the two optional protocols related to this Convention: The Optional Protocol to the Convention on the Rights of the Child on the involvement of Children in Armed Conflict and the Optional Protocol to the Convention on the Rights of the Child on the Sale of Children, Child Prostitution and Child Pornography, both signed on September 8, 2000 .

${ }^{8}$ The extent of Nigeria's obligation to the right to health is further examined in the last section of this article

9 See Preamble of the Constitution of the World Health Organization in UN General Assembly, Constitution of the World Health Organization (17 November 1947, A/RES/131). Also available at

$<$ http://www.who.int/governance/eb/who_constitution_en.pdf> accessed 15 January 2014.

${ }^{10}$ Valentina Vadi, Public Health in International Investment Law and Arbitration (Routledge 2012) 28.

${ }^{11}$ For instance, the fifth recital of the Preamble to the Universal Declaration of Human Rights (UDHR) of 1948 states that [...] the peoples of the United Nations have in the Charter reaffirmed their faith in fundamental human rights, in the dignity and worth of the human person and in the equal rights of men and women and have determined to promote social progress and better standards of life in larger freedom.

Article 25(1) further provides that

Everyone has the right to a standard of living adequate for the health and well-being of himself and of his family, including food, clothing, housing and medical care and necessary social services, and the right to security in the event of unemployment, sickness, disability, widowhood, old age or other lack of livelihood in circumstances beyond his control.

12 See also Paul Hunt and Rajat Khosla, 'The Human Right to Medicines' (2008) 5(8) Sur. Revista Internacional de Direitos Humanos 99 , 105.

${ }^{13}$ The Article imposes an obligation on State Parties
} 
17, 23 and explicitly outlined in Article 24 of the Convention on the Rights of the Child. ${ }^{1}$ These conventions recognise the fundamental right of everyone to medical care, health facilities and access to treatments as constitutive components of the right to the 'highest standard' of health. Specifically, the expansive provisions on the right to health in Article 24 of the Convention on Rights of the Child aim to address and reduce child mortality and ensure that every child is provided with, and has access to adequate healthcare services and facilities. It also includes the obligation on states to provide the necessary medical care and facilities for the reproductive, prenatal and postnatal care of mothers.

The African Charter on Human and People's Rights of 1981 (African Charter) in Article 16(1) also provides that every person is entitled to the 'best attainable state of physical and mental health.' ${ }^{2}$ The Article obligates states to take expedient measures to protect the health of their citizens and respond to their medical needs. ${ }^{3}$ The effect of the right to health in the African Charter was established in Purohit and Another $v$ The Gambia. $^{4}$

In this case, the applicants alleged, amongst other things, that the legislative regime in The Gambia for mental health patients violated the right to enjoy the best attainable state of physical and mental health (Article 16) and the right of the disabled to special measures of protection in keeping with their physical and moral needs. Holding that The Gambia fell short of satisfying the requirements of Articles 16 and 18(4) of the African Charter, the African Commission stated that the enjoyment of the right to health is crucial to the realisation of other fundamental rights and freedoms and includes the right of all to health facilities, as well as access to goods and services, without discrimination of any kind.

The ICESCR provides the most comprehensive provision on human rights to health as part of the sociocultural and economic aspect of human rights. The right in Article 12(1) is in two parts as follows: the first gives a general recognition of the rights of everyone to 'the highest attainable standard of physical and mental health.' Having reaffirmed the rights of everyone to health, the second aspect of the right in Article 12(2) exhorts a duty on State Parties such as Nigeria, to take the necessary steps to guarantee and ensure the full realisation of the rights by providing the necessary health-related resources (medicines), facilities, environment, information and conditions. $^{5}$

\subsubsection{Approaching Women's Health as a Human Right}

In addition to the above stated general entitlement of every person to the right to health and healthcare, the specific rights of women to health is recognised in several human rights instruments. The Protocol to the African Charter on Human and People's Rights of Women in Africa is a significant human rights instrument that reaffirms and promotes women's health and reproductive rights in Article $14{ }^{6}$ The Article particularly pays attention to the guarantee, protection and promotion of women's reproductive health. Article 14(2)(a) requires the states, such as Nigeria, to undertake all necessary actions to ensure women's access to adequate, affordable and accessible health services which will also include medicines. In addition, the 1995 Beijing Declaration and Platform for Action ${ }^{7}$ explicitly recognise women's reproductive rights and also, the entitlement of all women to healthcare and access to adequate medicinal treatments as essential to their sustainable development and empowerment. ${ }^{8}$ Furthermore, the Beijing Declaration obliges states to '[g]ive higher priority to women's health

[t]o prohibit and to eliminate racial discrimination in all its forms and to guarantee the right of everyone [...] to public health, medical care, social security and social services.

${ }^{1}$ The Convention was adopted and opened for signature, ratification and accession by General Assembly resolution $44 / 25$ of 20 November 1989. The Convention entered into force on September 1990.

The Convention in Article 24(1) states as follows:

States Parties recognize the right of the child to the enjoyment of the highest attainable standard of health and to facilities for the treatment of illness and rehabilitation of health. States Parties shall strive to ensure that no child is deprived of his or her right of access to such health care services.

${ }^{2}$ See Article 16(1) of the African Charter on Human and Peoples' Rights (African Charter) (Nairobi, 27 June 1981 , entered into force 21 October 1986, 1520 UNTS 217) (Banjul Charter) (Hereinafter African Charter)

${ }^{3}$ Article 16 (2), African Charter of 1981.

${ }^{4}$ (2003) AHRLR 96.

5 The necessary steps to be taken include:

(a) The provision for the reduction of the stillbirth-rate and of infant mortality and for the healthy development of the child;

(b) The improvement of all aspects of environmental and industrial hygiene;

(c) The prevention, treatment and control of epidemic, endemic, occupational and other diseases;

(d) The creation of conditions which would assure to all medical service and medical attention in the event of sickness.

United Nations General Assembly, International Covenant on Economic, Social and Cultural Rights (Adopted 16 December 1966 , entry into force 3 January 1976, United Nations Treaty Series volume 993, 3)

${ }^{6}$ Article 13(i) also guarantees adequate and paid pre- and post-natal maternity leave in both the private and public sectors

${ }^{7}$ The Beijing Declaration and Platform of Action was adopted at the Fourth World Conference on Women, convened by the UN in Beijing, China, in 1995. The Declaration and Platform of action is a commitment by governments and a global framework of action and blueprint for advancing women's rights, promoting gender equality, and opportunities for the empowerment of all women. The Declaration and Platform of Action, reinforces the human rights provisions in CEDAW although the commitments and promises are not legally binding. See more at UN Women, Beijing Declaration and Platform for Action: Beijing +5 Political Declaration and Outcome (UN Women 2014).

${ }^{8}$ Paragraph 27 and 30 of the Beijing Declaration and Platform for Action Fourth World Conference on Women Beijing Declaration 1995. 
and develop mechanisms for coordinating and implementing the health objectives of the Platform for Action and relevant international agreements to ensure progress.' ${ }^{1}$

The 1979 Convention on the Elimination of All Forms of Discrimination against Women (CEDAW) is one of the most significant legal instrument guaranteeing women's right to health. ${ }^{2}$ The protection of women's human right to health in CEDAW is characterised in two aspects: the first addresses gender discrimination and equality between men and women; while the second part promotes the realisation of the specific, collective and individual rights of women in all areas of their lives including their rights to health and access to basic healthcare services and medicinal treatments in the interests of their human rights. ${ }^{3}$

\subsection{Constitutional Recognition of Healthcare in Nigeria}

In Nigeria, although the 1999 Constitution (as amended) does not expressly recognise the right to health, the country's commitment to provide healthcare to its people is subsumed under the general provisions on health in the Fundamental Objectives and Directive Principles of State Policy in Chapter II of the Constitution. Section 17(3)(d) of the Constitution requires the state (Nigeria) to take appropriate measures and direct its policies towards ensuring an adequate standard of medical care for everyone, including the provision of medical and healthcare facilities. ${ }^{4}$ Under that section, the state shall also ensure that 'the health, safety and welfare of all persons in employment are safeguarded and not endangered or abused.' ${ }^{5}$ It can be said that these Fundamental Objectives and Principles consider it a primary duty of the state to improve the healthcare and welfare of Nigerians. ${ }^{6}$ For this reason, it imposes a liability on the state to secure the necessary facilities for the promotion of health and wellbeing of all Nigerians. ${ }^{7}$

While this blanket provision does not effectively address the issues of rights to health and access to adequate medical treatments in Nigeria, it could be argued that the Constitution's reference to 'adequate medical and health facilities' accords recognition to the appropriate health services and medicines as necessary for the improvement of the health and health-related conditions of Nigerians. Thus, the Nigerian government has a duty to promote the welfare of every individual, including the guarantee of their healthcare-related interests such as accessibility to medicines as part of medical care. This fundamental obligation of the government is supported by Section 14(1)(2) of the Constitution which enjoins the state to promote social justice, including the security and welfare of Nigerians, as a matter of public good. It could be argued that the obligation to promote the welfare and wellbeing of Nigerians could be discharged by providing adequate healthcare services and drugs for effective treatments of diseases and illness. A broad interpretation of this obligation also extends to ensuring that patents do not obstruct access to medicines or interfere with healthcare provision.

\subsubsection{Is Access to HealthCare and Medicines Legally Enforceable in Nigeria?}

Notwithstanding the provisions of Sections 17(3)(b) and (c) of the Constitution, there are two identifiable problems with the categorisation of the healthcare provision in Chapter II of the Nigerian Constitution. First, it is unenforceable by the courts; and secondly, the provision is not a 'human right.'

The categorisation of healthcare as a Fundamental Objective and Directive Principle as contained in Chapter II of the 1999 Constitution has been characterised as 'an aspirational or hortatory goal' with no legally binding claim. ${ }^{8}$ This is because the duty on the state to provide adequate healthcare facilities including medicines, in accordance with section $17(1)(\mathrm{c})(\mathrm{d})$ in Chapter II of the Constitution, falls under one of the judicially unenforceable categories of duties and responsibilities within the contemplation of Section 6(6)(c) of the Nigerian 1999 Constitution.

This commitment was also reaffirmed in the Beijing Declaration and Platform for Action Beijing, Political Declaration and Outcome in paragraph 55. See more discussions on this at Population Council, 'World Conference on Women: The Beijing Declaration and the Platform for Action on Women and Health' (1995) 21(4) Population and Development Review 910-911.

${ }^{1}$ Article 111(c) of The Beijing Declaration and Platform of Action, 1995.

${ }^{2}$ UN General Assembly, Convention on the Elimination of All Forms of Discrimination Against Women (Adopted 18 December 1979 , entry into force 3 September 1981 UNTS 1249, 13). Also available at

$<$ http://www.un.org/womenwatch/daw/cedaw/>accessed 17 July 2015.

${ }^{3}$ Rebecca J Cook, Women's Health and Human Rights (World Health Organization 1994) 19-20.

${ }^{4}$ It reads:

The State shall direct its policy towards ensuring that-

(d) there are adequate medical and health facilities for all persons.

The health and safety of people in the workplace are also accorded recognition in section 17(3)(c) of the Constitution.

${ }^{5}$ 17(3)(c) 1999 Constitution of Federal Republic of Nigeria 1999 Cap. C23 Laws of Federation of Nigeria 2004.

${ }^{6}$ In the case of Attorney-General of Ondo State v Attorney-General of the Federation (2002) FWLR (pt. 111) 1972, the Nigerian Supreme Court per Uwaise, JSC clarified that the word 'state' applies to all tiers of government, authorities and persons exercising legislative, executive or judicial powers with regards to the enforcement of the Fundamental Objectives and Directive Principles of State Policy under the Constitution.

${ }^{7}$ Oyeniyi Ajigboye, 'Realization of Health Right in Nigeria: A Case for Judicial Activism' (2014) 14(3) Global Journal of Human Social Science Research 23, 24.

${ }^{8}$ Obiajulu Nnamuchi, 'Kleptocracy and its Many Faces: The Challenges of Justiciability of the Right to Health Care in Nigeria' (2008) 52 Journal of African Law 1, 2. 
By virtue of Section $6(6)(\mathrm{c})$ of the Constitution, the courts lack jurisdiction to entertain issues emanating from the socio-economic and cultural aspirations and objectives in the Fundamental Objectives and Directive of Principles of State Policy in Chapter II of the Constitution. Under Section 6(6)(c), the judicial powers vested in accordance with the provisions of Chapter II in the Constitution,

[...] shall not except as otherwise provided by this Constitution, extend to any issue or question as to whether any act of omission by any authority or person or as to whether any law or any judicial decision is in conformity with the Fundamental Objectives and Directive Principles of State Policy set out in Chapter II of this Constitution.

Consequently, the justiciability of the socio-economic guarantees in the Constitution or any other law is clear. ${ }^{1}$ Accordingly, Section 6(6)(c) implies that an aggrieved person cannot take the government to court, or seek a judicial remedy for a violation of the provisions of Chapter II. ${ }^{2}$ As Section 17(1)(c)(d) falls within the provision of the Fundamental Directives in Chapter II, the restrictions on judicial enforceability apply to the duty to provide healthcare facilities. In essence, a claim to medical and healthcare treatments in Nigeria has no judicial enforceable status under the Constitution. This means that in the Constitution, interference with access to healthcare services and medicines cannot be redressed through judicial channels by Nigerians. A further implication is that the government of Nigeria cannot legally be compelled to implement its obligations to provide medical and healthcare facilities under the Constitution.

Although the necessity of directing state policies towards facilitating access to medical and healthcare facilities to further the material wellbeing of Nigerians was promoted in the Constitution, the status of this provision as a non-justiciable entitlement robs the provisions of a judicial recourse to compel government compliance, action and enforcement. Thus as it stands, the provision is a mere political objective and goal, devoid of a concrete redress mechanism against the duty bearers to guarantee the enjoyment of these important provisions on health. This leads academicians and legal specialists to criticise the categorisation of the obligations to which the provision on healthcare in the Constitution belongs as a 'toothless bulldog' that barks but cannot bite because there are no concrete enforcement mechanisms attached to the health objective. ${ }^{3}$

The Nigerian courts have generally adopted the same attitude to the non-justiciability of the socio-economic provisions in Chapter II and have upheld the unenforceability of its provisions. For instance, the Nigerian Court in Archbishop Anthony Olubunmi Okogie (Trustee of Roman Catholic Schools) \& Others vs Attorney General of Lagos State, ${ }^{4}$ reaffirmed the challenge that Section 6(6)(c) poses to the judicial application of the Chapter II provisions by the courts, thus raising the questions of how and whether the provisions are actually 'fundamental' since they cannot command judicial enforcement. ${ }^{5}$ In this case, the courts were invited to adjudicate on the question of the enforceability of the fundamental rights of the plaintiffs. The Lagos State Government issued circulars to abolish all private fee paying primary educational institutions. This was done 'towards ensuring that there are equal and adequate educational opportunities at all levels' as provided under Section 18 of the 1979 Constitution (a non-justiciable provision in the 1979 Constitution). The plaintiff claimed that the plan by the government to abolish private primary education was a threat to the freedom to hold and impart education under Section 36 of the Constitution. The Court of Appeal reaffirmed in its ruling pursuant to Section 6(6)(c), that the provisions of Chapter II were not enforceable in courts. The court proceeded on the general note that the provisions in Chapter II are not justiciable, and that 'the arbiter for any breach of the Objectives and the Directive Principles of State policy is the legislature or the electorate. ${ }^{6}$ Delivering the ruling, Justice Mamman Nasir (as he then was) acknowledged that the directive principles are the ultimate objectives of the nation and are policies which are expected to be pursued in the nation's interest to realise its welfare objectives. He explained further that,

[w]hile Section 13 of the Constitution makes it a duty and responsibility of the judiciary among other organs of government, to conform to and apply the provisions of Chapter II, Section $6(6)(c)$ of the same Constitution makes it clear that no Court has jurisdiction to pronounce any decision as to whether any organ of government has acted or is acting in conformity with the Fundamental Objectives and Directive Principles. It is clear that Section 13 has not made Chapter II justiciable. ${ }^{7}$

Ruling in favour of the plaintiff's fundamental rights, the court further held that no legislation, pursuant to Section 16 or 18 of the Constitution can validly override the constitutionally guaranteed rights in Chapter IV of

\footnotetext{
${ }^{1}$ Olisa Agbakoba and others, Towards a Peoples' Constitution in Nigeria: A Civic Education Manual for the Legal Community (Human Rights Law Service 2002) 43, 58.

2 ibid 43,58 .

${ }^{3}$ Nnamuchi (n 30) 2.

${ }^{4}$ (1981) 2 NCLR 350. The reasoning in the above decision was affirmed in the later case of Adewole v Jakande (1981) 1 N.C.L.R. 152. This is another case which arose over the abolition of private elementary schools in Lagos State.

${ }^{5}$ Dejo Olowu, An Integrative Rights-based Approach to Human Development in Africa (PULP 2009) 174.

${ }^{6}$ Paragraphs 7-8.

${ }^{7}$ Paragraphs 1-2.
} 
the Constitution.

Likewise in Uzoukwu v Ezeonu II the Courts, per Nasir PCA, reiterated the non-justiciability of Chapter II thus:

There are other rights which may pertain to a person which are neither fundamental nor justiciable in the Court. These may include rights given by the Constitution under the Fundamental Objectives and Directive Principles of State Policy under Chapter II of the Constitution. ${ }^{1}$

In this case, the appellants sought the enforcement of their fundamental rights, as guaranteed by Sections 31 and 39 of the 1979 Constitution. They alleged that the respondents treated and regarded them as slaves, in violation of their Constitutional guaranteed rights. The court in its ruling clarified that while the fundamentally ascribed rights in Chapter IV are justiciable in courts, the rights given by the Constitution in Chapter II are not fundamental or justiciable in Courts. ${ }^{2}$ It is unfortunate that despite the importance of the socio-economic and cultural provisions in Chapter II, their practical enforceability has been undermined by the same Constitution that pledged to promote the welfare and wellbeing of all persons in Nigeria.

Another issue is that the provisions on health in the Constitution are not 'human rights'; they are fundamental state objectives and principles which the Nigerian state aims to achieve for all its citizens. While the importance of protecting human rights in national constitutions is without doubt significant to guaranteeing the enjoyment of the rights, the Nigerian Constitution has failed to accord the provisions in Chapter II with human rights status. Although the provisions embody socio-economic and cultural rights, the heading, focus, goals and procedural judicial embargo clearly indicate that the provisions are not guaranteed human rights. Indeed, while Chapter IV of the Constitution is entitled 'Fundamental Rights, Chapter II has the heading 'Fundamental Objectives and Directives of State Policy.' If the intention of the legislature was to make the provisions in Chapter II human rights, it would have clearly stated so. Thus, despite the significance of access to medicines as a human right to health and the need to ensure that medical patents do not interfere with this access from a human rights perspective, the Constitution has failed to effectively reflect a human rights goal to the provision on health.

It is argued that there is a need to guarantee the provisions in Chapter II as legally enforceable human rights. Under international law, as discussed above, the provisions on human rights carry with them obligations for the state to respect, protect, fulfil and implement. This duty includes ensuring that policies and laws such as patents do not interfere with the enjoyment of the right. As justiciable human rights, the provisions on health would also avail Nigerians with the opportunity and legal recourse to measure the performance of the government, authorities and third parties who infringe on those rights. However, the failure to guarantee the provisions on health as human rights under the Constitution means that the provisions may not make full meaningful impact on all Nigerians, especially since the provisions are non-justiciable.

Moreover, it is argued that the extant legislative provision on healthcare in the Constitution is inadequate to capture all the dimensions of the right to health. The provision in Section 16(3)(d) simply obliges the state to direct its resources towards providing 'adequate medical and health facilities for all persons.' This language of the law does not guarantee all the dimensions of the right to health. From the lens of access to medicines perspective, the text of the law with regards to health does not appear to clearly guarantee the availability and accessibility of affordable drugs that are acceptable and of good quality, in a gender sensitive and nondiscriminatory manner. Nevertheless, a broad interpretation of the measures to be undertaken to provide the medical and health facilities in the Constitution would require that health medicines are provided and any interference with accessing medicines is addressed by the Nigerian state. For the sake of brevity, however, the recognition of the provisions on adequate healthcare in the Constitution as human rights would ensure that all components of the right to health including access to medicines are guaranteed.

This suggestion is consistent with the preamble to the Constitution which pledges to promote the wellbeing of Nigerians. But without access to adequate healthcare and medicines, securing the wellbeing of the Nigerian women, and indeed all Nigerians will remain a pipe dream. Thus it is important that the healthcare of the citizens is given paramount importance as a matter of right in the country.

\subsubsection{Making a Case for the Provision of Healthcare and Access to Medicines for Women under the Nigerian Constitution}

The Drafting Committee of the 1979 Constitution ${ }^{3}$ characterised the 'Fundamental Objectives' as the 'identification of the ultimate objective of the nation'. As such, they are the 'ideals towards which the Nation is expected to strive' to promote the security and welfare of the people. ${ }^{4}$ The 'Directive Principles', on the other

\footnotetext{
${ }^{1}$ (1991) 6 NWLR (pt 2000) 761, paragraphs A-D.

2 ibid

${ }^{3}$ The precursor to the current 1999 Constitution. The Constitution was the first to categorise the Fundamental Objectives and Directive Principles on state policy provisions.

${ }^{4}$ Report of the Constitution Drafting Committee Vol 1 (Government Printer 1976) v. Accordingly, the 'Fundamental Objectives are ideals towards which the Nation is expected to strive whilst Directive Principles lay down the policies which are expected to be pursued in the
} 
hand, 'lay down the policies which are expected to be pursued in the efforts of the Nation to realise the national ideals.' ${ }^{1}$ In other words, the Principles are identified as the guidelines which lead to the realisation of state ideals or goals; hence the state is expected to direct its policies to achieve these ideals. For this purpose, Section 13 of the 1999 Constitution states:

It shall be the duty and responsibility of all organs of government, and of all authorities and persons, exercising legislative, executive or judicial powers, to conform to, observe and apply the provisions of this Chapter [Chapter II]. ${ }^{2}$

This provision, however, leaves a myriad of questions open. Such as: what is the nature of duty and responsibility that the state is expected to adopt to comply with the requirement to fulfil the obligation to medical and healthcare facilities for women pursuant to Section 17(3)(c) and (d)? In other words, to what extent is the government expected to satisfy the duty to 'conform to, observe and apply the provisions' on guaranteeing their access to healthcare facilities including medicines? More specifically, if the state fails in its duty, how can it be compelled to meet its responsibility and duty to healthcare, considering the fact that their recourse to a legal remedy has been foreclosed?

Where there is a duty, there is a corresponding obligation to fulfil that duty, and a remedy mechanism to enforce compliance with that duty; yet Section 6(6)(c) of the Constitution exempts this duty from judicial scrutiny. Can it be said then that there is no actual duty on the state to implement the provision on access to adequate medical care because it is not legally binding?

Neither Section 13 nor any other section in the Constitution gives a clear answer to these questions. However, it is argued that, although the provision of access to adequate healthcare cannot compel judicial legal recourse, it does not affect the duty and responsibility of the Nigerian state to implement, apply and observe the statutory provisions of Section 17(3)(c) and (d) with regards to facilitating and protecting women's access to adequate medical care. In other words, the absence of a justiciable statute does not divest the state of a duty to protect, promote and realise its duty to the provision of medical care. One scholar, commenting on the nature of the government's duty, argues that the word 'Directive' in the title of Chapter II implies that this duty is mandatory and the provisions create an obligation on the government to fulfil and comply with the provisions on access to adequate health and medical facilities. ${ }^{3}$ Accordingly, the term 'Directive' in Chapter II suggests that it is an order or command, meaning that the provisions of the Chapter are obligatory and create commitments for the government to comply. ${ }^{4}$ In agreement with the above suggestion, it appears that the duty with respect to adequate medical and health facilities, including access to medicines, is couched in an authoritative or mandatory term which requires the state to achieve the intended outcome. Clearly, Section 6(6) (c) only purports to exclude the legal enforcement of a claim on this duty or a violation of the Fundamental Directives by foreclosing the possibility of subjecting the positive realisation of the provisions in Chapter II to judicial scrutiny.

Notwithstanding this judicial bar, the state has a duty to direct its policies towards ensuring women's access to adequate healthcare facilities and medical treatments. That is, the non-enforceability of the provision does not negate the fact that the state has a duty to ensure that its policies and laws guarantee women and indeed all Nigerians access to health facilities including medicines, even though this duty cannot command the force of law in a judicial proceeding. In addition, as Nwabueze observes, the provisions of Chapter II can be relied upon in the interpretation of constitutional debates. ${ }^{5}$ In this regard, it can be said that the provisions of Section 17(3)(c) can be relied upon to argue that the state direct its policies to ensuring that there is non-interference with women's healthcare in view of patent rights, or utilise the patent-related flexibilities to guarantee their access to adequate medical care. India's attitude to the constitutional provision on health offers a good example to support these arguments.

The Fundamental Objectives and Directives in Chapter II of the extant Nigerian Constitution (including the provision on health and medical care) is borrowed from the Indian Constitution (1948) and was first included in the 1979 Nigerian Constitution. ${ }^{6}$ India's present constitutional provision on the rights to health and healthcare is, however, extensive and covers a wider range of conditions for public health and wellbeing of everyone. ${ }^{7}$ For

efforts of the Nation to realise the national ideals.'

${ }^{1}$ ibid v; JO Debo Akande, The Constitution of the Federal Republic Of Nigeria, 1979: With Annotations (Sweet \& Maxwell 1982) 13; B Okere 'Fundamental Objectives and Directive Principles of State Policy under the Nigerian Constitution' (1983) 32 International and Comparative Law Quarterly 214.

${ }^{2}$ Emphasis added.

${ }^{3}$ Nnamuchi (n 30) 4.

${ }^{4}$ ibid

${ }^{5}$ Remigius N Nwabueze, 'The Legal Protection and Enforcement of the Health Rights in Nigeria' in Colleen M Flood and Aeyal Gross (eds), The Right to Health at the Public/Private Divide: A Global Comparative Study (Cambridge University Press 2014$) 381$.

${ }^{6}$ ibid 381. The Fundamental objectives and directive principles first appeared in the Constitution of 1979, and are similar to Part IV of the Constitution of India 1949, as amended in 1951. J Akande, The Constitution of the Federal republic of Nigeria 1979 with Annotations (Sweet \& Maxwell 1982) 13

${ }^{7}$ The obligation on the state to ensure, create and sustain the necessary facilities and conditions congenial to good health is generally found in the Constitutional directives as contained in Articles 38, 39(e)(f), 41, 42, 47 and 48A in Part IV of the Constitution of India. For example, 
example, the state in Article 47 has a primary duty to secure the public health of the people by 'raising the level of nutrition and standard of living [...] and the improvement of public health [...]' including control of substances that affect health and human conditions of work. Notably, Article 42 recognises the importance of women's health and makes provisions to secure 'maternity reliefs' and benefits as being integral to health. ${ }^{1}$ Similarly to Nigeria, the provisions on health are not legally enforceable by the courts in India. ${ }^{2}$ Notwithstanding, the Indian courts have broadly construed the constitutional provisions on health to enforce the state's obligation to improve the health and rights of the people to affordable healthcare, especially medicines. ${ }^{3}$

In Samity v State of Bengal, for instance, access to timely healthcare necessary to preserve life was upheld by the Indian Supreme Court. ${ }^{4}$ Deciding on the basis of the right to life, the court held that the right includes an obligation to provide access to medical treatments to preserve human life as a 'constitutional obligation of the state to provide adequate medical services to the people. ${ }^{5}$ Perhaps, it is not out of place for Nigeria to follow this judicial activism and adopt a rights-based attitude to lay down the standards for the Nigerian state to comply with its obligations to women's health. ${ }^{6}$

Still on the issue, how then can an aggrieved person compel the enforcement of the duty to comply, enforce and observe the provisions of access to healthcare? The answer to this question remains unclear. However, despite the non-enforceability and justiciability challenge of Chapter II, the Nigerian courts have begun to open up new windows to allow the enforcement of the constitutional provisions in Chapter II including the recognition of the health provisions as rights. The court generally relies on the justiciable fundamental rights in Chapter IV of the Constitution to interpret the non-justiciable provisions. For instance, in the case of Gbemre v Shell Petroleum Development Company Nigeria Limited and Others ${ }^{7}$ the Nigerian Federal High Court delivered a landmark ruling for the protection of right to health and a healthy environment. In that case, the appellants sought an order to enforce their fundamental rights to life and dignity of person pursuant to Sections 33(1) and 34(1) of the Nigerian Constitution. The applicants supported their claim by relying on Articles 4, 16, and 24 of the African Charter. ${ }^{8}$ They claimed that the degradation of the environment by the respondents violated their human rights to a healthy environment. The respondents counter-argued that the African Charter and its provisions on health and healthy environment do not create justiciable and legally enforceable rights in regular Nigerian courts. The judge, Nwokorie J, rejected the arguments of the respondents and ruled that the provisions of the Charter are applicable in Nigeria.

The Courts further held that:

That section 3(2)(a) and (b) of the Associated Gas Re-Injection Act and section 1 of the Associated Gas Re-Injection (Continued Flaring of Gas) Regulations section 1.43 of 1984, under which gas flaring in Nigeria may be allowed are inconsistent with the applicant's rights to life and/or dignity of human person enshrined in sections 33(1) and 34(1) of the Constitution of the Federal Republic of Nigeria, 1999 and articles 4, 16 and 24 of the African Charter on Human and Peoples' Rights (Ratification and Enforcement) Act, cap A9, Vol 1, Laws of the Federation of Nigeria, 2004) and are therefore unconstitutional, null and void by virtue of section 1(3) of the

\footnotetext{
Article 41 states that the

State shall, within the limits of its economic capacity and development, make effective provision for securing the right to work, to $[\ldots]$ public assistance in cases of [...] old age, sickness and disablement $[. .$.$] .$

${ }_{1}^{1}$ Indrajit Khandekar, BH Tirpude and PN Murkey, 'Right to Health Care' (2012) 34 (2) Journal of Indian Academy of Forensic Medicine 160. ${ }^{2}$ Ebenezer Durojaiye, 'Litigating the Right to Health in Nigeria: Challenges and Prospects' in Magnus Killander (ed), International Law and Domestic Human Rights Litigation in Africa (PULP 2010) 166. The provisions guaranteeing healthcare and health conditions in India are found under the Directive Principle of State policy which is not justiciable in India. Article 37 of the Constitution declares that the [t]he provisions contained in this Part shall not be enforceable by any Court, but the principles therein laid down are nevertheless fundamental in the governance of the country and it shall be the duty of the State to apply these principles in making laws.

${ }^{3}$ See discussions and cases on this in Mihir Desai and Dipti Chand, 'Fundamental Right to Health and Public Health Care' in Mihir Desai and Kamayani Bali Mahabal (eds), Health Care Case Law in India (Centre for Enquiry into Health and Allied Themes (CEHAT) and India Centre for Human Rights \& Law (ICHRL) 2007) 17-35.

${ }^{4}$ Paschim Banga Khet Samity v State of West Bengal, Case No. 169, Judgement of 6 May 1996 Writ Petn. (Civil) No. 796 of 1992 (SC Agrawal, GT Nanavati JJ) (1996). In this case, Samity fell off a train and suffered serious head injuries. The necessary health facilities (including vacant bed) to treat him were not available in six hospitals. The Court held that 'failure on the part of the government to provide timely medical care to a person in need of such treatment results in a violation of his right to life guaranteed in Article 21 of the Constitution. See paragraph 9 of the judgement.

${ }^{5}$ Paragraphs 9, 15-16 ibid. Notably, the court held that this duty on the state is irrespective of financial and resource constraints and the state responsibility can be discharged in 'whatever is necessary for this purpose.' Paragraph 16 ibid.

${ }^{6}$ It should be noted that Nigeria shares a similar constitutional law and legal system with India hence the comparative study of Nigeria and India. This suggestion is made not only because Nigeria and India share a similar constitutional provision with regards to healthcare, but more so that both countries share a comparable socio-economic condition and political landscape.

7152 (2005) AHRLR 151 (NgHC 2005).

${ }^{8}$ Article 4 on the right to life, 16 on the right to health care and 24 on right to satisfactory environment in the African Charter. On the right to health provisions in African Charter, the appellant argued that they have a right to 'enjoy the best attainable state pf physical and mental health as well as a right to a general satisfactory environment favourable to their development.'
} 
same Constitution. ${ }^{1}$

In this case, the judge relied on the guaranteed constitutional provisions on the rights to life and dignity of person and broadly construed the right to life as extending to the right to health and a healthy environment under the ratified African Charter.

This case is a significant improvement in the judicial attitude to human rights, especially socio-economic provisions, for the following reasons. Firstly, the case was the first time a Nigerian court had made a pronouncement on the right to health and a healthy environment. Importantly, the court linked the right to a healthy environment (non-justiciable under Chapter II) with the justiciable right to life and human dignity provision in the 1999 Constitution. The right to life was thus broadly interpreted to include congenital factors such as a healthy living environment. Secondly, although the case was not decided exclusively on the human rights provisions in the African Charter, the court significantly relied on the right to health and healthy environment in the Charter to enforce socio-economic rights in Nigeria. Thirdly, this case also illustrates the influence and application of human rights provisions in the African Charter to grant a human rights remedy.

It follows that another way to secure the litigation of the provisions on health and access to medicines in Nigeria is by linking the enforcement of the provisions in Chapter II to the justiciable rights such as the right to life, dignity and liberty. ${ }^{2}$ This way, an action for the violation of the rights to health which will face the challenge of justiciability under the constitution can be based on the right to life as discussed above. ${ }^{3}$ The argument can be made when asserting these claims that, although the access to adequate medical care including medicines in Chapter II may not be a legally guaranteed right, nonetheless, it is essential to the enjoyment of other guaranteed rights in the Constitution. ${ }^{4}$

Most people would agree that the right to life in Section 33(1) of the Nigerian Constitution is more meaningful to a healthy person. ${ }^{5}$ Likewise, without essential medicines, it will be hard for the Nigerian government to guarantee health, life and other socio-economic objectives and political rights of Nigerian women and all its citizens. Access to essential medicines as a part of providing adequate medical and healthcare facilities has implications for the enjoyment and realisation of the civil and politically justiciable rights in the Constitution. In guaranteeing the right to life, therefore, the government has a duty to take appropriate measures to the provision of adequate healthcare system and medicines for women and children and all Nigerians.

Other case studies also indicate that the non-justiciability status of Chapter II of the Constitution in Section 6(6)(c) of the Constitution may not be absolute and in some instances, the provisions in Chapter II can be made justiciable. ${ }^{6}$ The enforcement of Chapter II provisions is allowed where it is so provided under other sections of the Constitution. This argument is better explained in the case of Olafisoye v Federal Republic of Nigeria. ${ }^{7}$ In this case, the appellants were charged with offences under the Corrupt Practices and Other Related Offences Act, 2000. The Court was invited to determine the question of whether or not the National Assembly validly enacted the Corrupt Practices and Other Related Offences Act of 2000 in accordance with the powers conferred to the Government under Section 15(5)(2) of the Constitution. The Section, contained in Chapter II of the Constitution, grants powers to the National Assembly to make laws to prohibit and abolish corrupt practices and abuse of power. The Court in its ruling stated that Section 6(6)(c) does not completely foreclose the justiciability of Chapter II. In the words of Niki Tobi (JSC),

In my humble view section 6 (6) (c) of the Constitution is neither total nor sacrosanct as the subsection provides a leeway by the use of the words "except as otherwise provided by this Constitution." This mean that if the Constitution otherwise provides in another section, which makes a section or sections of Chapter 11 justiciable, it will be so interpreted by the Courts.

The Supreme Court also based its decision on the provisions of Item 60(a) of the Exclusive legislative list of the Second Schedule to the Constitution which vests power in the National Assembly to promote and enforce the observance of Chapter II. ${ }^{8}$ Accordingly, the court ruled that the legislature validly exercised its rights in the

\footnotetext{
${ }^{1}$ Paragraph 5(6)

${ }^{2}$ For example, in Archbishop Anthony Olubunmi Okogie \& Ors v Attorney General of Lagos State, (n 306), although the courts held that the Fundamental Directives and State Policy were non-justiciable, at the same time, the Court of Appeal held that the implementation of Chapter II could not be done in such a way as to infringe on the fundamental rights enunciated in Chapter IV of the Constitution (the freedom to hold opinion, receive and impart ideas under Section 36(1) of the Constitution). The court further found in favour of the plaintiffs on the basis that Sections $16(1)(\mathrm{c})$ and 18 of the Constitution guarantee their rights to participate in the economy and hindering them would amount to a violation of their fundamental rights under Section 36 - freedom to hold, receive and impart ideas.

${ }^{3}$ Ebenezer Durojaiye, 'Litigating the Right to Health in Nigeria: Challenges and Prospects' in Magnus Killander (ed), International Law and Domestic Human Rights Litigation in Africa (PULP 2010) 166-167.

${ }^{4}$ Nnamuchi (n 30) 8; Agbakoba and others (n 31) 42.

${ }^{5}$ The Nigerian Constitution in Section 33(1), 34 and 35 explicitly recognises the right of everyone to life, human dignity and liberty

${ }^{6}$ GN Okeke, 'The Justiciability of the Non-Justiciable Constitutional Policy of Governance in Nigeria' (2013) 7 IOSR Journal of Humanities and Social Science 9, 11.

${ }^{7}$ (2004) 4 NWLR (Pt. 864) 580.

8 The sub-item provides:

The establishment and regulation of authorities for the Federation or any part thereof -
} 
exclusive list.

In view of the foregoing, it appears that while Chapter II is non-justiciable, there are other ways which the provisions can be made justiciable. Pursuant to Section 4(2) of the 1999 Constitution, the National Assembly has the exclusive power to make laws for the peace, order and good government of the Nigerian Federation with regards to any matter in the Exclusive List. Equally, under Item 60(a) of the Exclusive List of the Constitution, the legislature has the power to promote and enforce the realisation of the provisions of Chapter II (which contains provisions on Nigeria's access to adequate healthcare facilities and medicines). ${ }^{1}$ This power extends to the establishment and regulation of the appropriate authorities for this purpose. ${ }^{2}$ The provisions of Section 4(2) and Item 60(a) essentially give teeth to the enforcement of Chapter II. As the matter of regulating Chapter II provisions falls under the Exclusive Legislative List, the National Assembly can make laws with respect to the implementation and enforcement of the provisions of Chapter II. Since the bar to the enforceability of Chapter II does not extend to matters in the Exclusive List, it can be argued that the legislature in Nigeria can make laws that permit the enforceability of the provisions of Chapter II, notwithstanding the bar in Section 6(6)(c). In this connection, Obilade noted with respect to the duties of the state to abolish corrupt practices and the abuse of power that

[i]t is clear [...] that although Section 15(5) [in Chapter II] of the Constitution is, generally not

justiciable, as soon as the National Assembly exercised its powers under Section 4 of the Constitution with respect to Item 60(a) of the Exclusive Legislative List, the provisions of Section 15(5) of the Constitution becomes justiciable. ${ }^{3}$

This argument also finds support in the case of Attorney General of Ondo State v Attorney General of the Federation \& Others. ${ }^{4}$ The Supreme Court adopted a liberal interpretation which suggests the likelihood of the justiciability of Chapter II through relevant federal legislation. One of the main issues before the court for determination in that case was the question of whether or not the National Assembly was competent to enact the Corrupt Practices and Other Related Offences Act of 2000 in relation to Section 15(5) (under Chapter II) as empowered under Item 60(a) of the Second Schedule to the Exclusive Legislative list. ${ }^{5}$ The court upheld and justified the enactment of the Act based on the legislative authority of the National Assembly under Items 60(a), 67 and 68 of the Exclusive Legislative List. ${ }^{6}$ On the non-justiciability of the Fundamental Objectives and

(a) To promote and enforce the observance of the Fundamental Objectives and Directive Principles contained in this Constitution.

${ }^{1}$ Pursuant to Section 4(2) of the Constitution, the legislative power is vested in the National Assembly of the federal Republic of Nigeria, consisting of the Senate and Federal House of Representatives, with regards to matters in the Exclusive List.

${ }^{2}$ For example, Justice Mohammed L Uwais CJN (as he then was) succinctly emphasised the importance of Item 60(a) thus:

Item 60 of the Exclusive Legislative List of the Constitution of the Federal Republic of Nigeria specifically empowers the

National Assembly to establish and regulate authorities for the Federation to promote and enforce the observance of the Fundamental Objectives and Directive Principles, and to prescribe minimum standards of education at all levels, amongst others. The breath-taking possibilities created by this provision have sadly been obscured and negated by non-observance. This is definitely one avenue that could be meaningfully exploited by our legislature to assure the betterment of the lives of the masses of Nigerians, whose hope for survival and development in today's Nigeria have remained bleak, and is continuously diminishing. The utilisation of this power would ensure the creation of requisite bodies to oversee the needs of the weak and often overlooked and neglected in our society. It would also provide a unique and potent opportunity to our legislators to monitor and regulate the functions of these bodies, where the Executive, for reasons best known to it, fails or neglects to prioritize and implement the provisions of Chapter II, and by extension, the welfare of all Nigerians

Mohammed L Uwais, 'Fundamental Objectives and Directive Principles of State Policy: Possibility and Prospect' in CC Nweze (ed), Justice in the Judicial Process: Essay in Honour of Honourable Justice Eugene Uba Ubaezonu (Fourth Dimension Publishing Company 2002 ) 179. ${ }^{3}$ AO Obilade and others (eds), Contemporary Issues in the Administration of Justice: Essay in Honour of Justice Atinuke Ige (Treasure Hall Konsult 2002) 127

${ }^{4}$ (2002) 9 NWLR (Pt 772) 222

${ }^{5}$ The plaintiffs challenged the constitutionality and validity of the Corrupt Practices and Other Related Offences Act of 2000 establishing the Independent Corrupt Practices and Other Related Offences Commission to prosecute alleged offenders in relation to Section 15(5) (under Chapter II) on the federalism principle. One of the questions before the Court was whether the National Assembly is constitutionally empowered to make laws with respect to 'all corrupt practices and abuse of power' in Section 15(5) under Item 60(a) of the Second Schedule to the Exclusive Legislative list.

${ }^{6}$ Similarly, in the case of Bamidele Aturu v Minister of Petroleum Resources and Others (2013) Suit No FHC/ABJ/CS/591/09, Aturu instituted an action challenging the incessant fuel price increases and the Nigerian government's neo-liberal policy of deregulation of the downstream sector of the petroleum industry. He argued that the policy of deregulation was unconstitutional and illegal in view of Section 16(1) of the Constitution (under Chapter II) and Sections 6(1) and 4(1) of the Petroleum Act and the Price Control Act, respectively. The defendants counter-argued that the suit was not properly constituted on the grounds of locus standi and non-justiciability of section $16(1)$. On the substantive issue, the court ruled that the combined reading of the provisions of section 16(1) of the Nigerian Constitution and sections 6(1) and 4(1) of the Petroleum Act and the Price Control Act respectively obliged the government to regulate and fix, from time to time, the price of petroleum products in Nigeria in such a manner as to secure the maximum welfare, freedom and happiness of Nigerian citizens. On the issue of justiciability, the court relied on Attorney General of Ondo State v Attorney General of the Federation \& Others (n 342) and held that the provisions of Chapter II of the Constitution can be made justiciable through legislation. The Court ruled that 'by enacting the Price Control Act and Petroleum Act and providing in section 4 and 6 of those acts, for the control and regulation of prices of petroleum products, the National Assembly working in tandem with the government has made the economic objectives in section 16(i) (b) of the Constitution in Chapter II justiciable.' See also Akinola E Akintayo, 'A Good Thing from Nazareth? Stemming the Tide of Neo-Liberalism Against SocioEconomic Rights: Lessons from the Nigerian Case of Bamidele Aturu v Minister of Petroleum Resources and Others' (2014) 15(2) ESR 
Directives of State Policy, Uwaifo S (JSC) ${ }^{1}$ adds as follows:

While they remain mere declarations, they cannot be enforced by legal process but (it) would be seen as a failure of duty and responsibility of State organs if they acted in clear disregard of them [...]. But the directive principles (or some of them) can be made justiciable by legislation.

Uwaifo further expounded on this thus:

The Constitution itself has placed the entire Chapter II [on Directive Principles] under the Exclusive Legislative List. By this, it simply means that all the Directive Principles need not remain mere or pious declarations. It is for the Executive and National Assembly, working together; to give expression to anyone of them through appropriate enactment as occasion may demand. ${ }^{2}$

This view of the judge gives credence to the opinion in this article that provision of healthcare including medicines and the regulatory measures to ensure that women's access to healthcare is not impeded is an obligation and possibly an enforceable duty on the Nigerian government. These judicial pronouncements significantly suggest that there are alternative and indirect means by which the provisions of Chapter II can be made justiciable by means of enacting and executing legislation to this effect. ${ }^{3}$ Thus it is possible that the provisions on access to adequate healthcare can be made justiciable through legislative provisions to bolster the effect of the provisions in Chapter II of the Constitution. ${ }^{4}$ However, the legislature has to make provisions to give applicability to them. ${ }^{5}$

\subsubsection{Current Measures to Promote the Right to Health in Nigeria}

Towards the promotion of the health and welfare of Nigerians, the National Health Act was signed into law in December 2014. The Act provides a policy framework for the enhancement, regulation and management of the national health system. Notably, it provides a framework to 'protect, promote, and fulfil the rights of the people of Nigeria to have access to healthcare service. ${ }^{6}$ Part of the healthcare services in the Act includes the duty to 'promote availability of good quality, safe and affordable essential drugs, medical commodities, hygienic food and water. ${ }^{7}$ It regulates both the private and public health service sectors and also creates a Basic Health Care Provision Fund to ensure access of every Nigerian citizen to healthcare services. The use of the word 'right' to denote the entitlements of Nigerians to a healthcare system is illustrative of the legislators' recognition of healthcare as an essential human right. ${ }^{8}$ It could be said that the Act imposes a human rights obligation on the state to provide healthcare to its citizens. Although not expressly stated in the Act, the obligation to provide healthcare and medicinal treatments will require the state to guarantee that its laws and policies, such as patent laws and the rights conferred on inventors do not hinder access to medicines. The Act is still at its nascent stage; it remains to be seen if it will live up to its objective of promoting access to quality healthcare for women and everyone in Nigeria.

\subsection{Nigeria's International Obligation to International Human Right Provisions Guaranteeing Rights to Health and Access to Medicines}

Nigeria, has committed itself to protect the rights to health and life under several international human rights instruments. This commitment to human rights imposes a duty on the state to fulfil its contractual obligation to

\section{Review.}

${ }^{1}$ Not the leading judge in the case.

${ }^{2}$ Uwaifo S (JSC) 391 paragraph(s) G- H, 410 paragraph G.

${ }^{3}$ Nwabueze (n 62) 382. See also the case of Federal Republic of Nigeria $v$ Anache and 3 ors. (2004) 17 NSCQR 140 where the court adopted the opinion that the phrase 'save as otherwise provided by this constitution' does not absolutely exclude matters in Chapter II from justiciability in the Constitution.

${ }^{4}$ See for example, the National Health Act which recognises Nigerians to a right to healthcare and services.

${ }^{5}$ In a related manner, in the 1999 Constitution, health is listed in Schedule II, Part II, Item 17(a) of the Concurrent list; however the wording of the Item indicates that the National Assembly is charged with the responsibility of making laws with respect to matters and issues relating to health.

Schedule II, Part II, Item 17(a) provides as follows that the National Assembly may make laws for the Federation or any part thereof with respect to: '[t] he health, safety and welfare of persons employed to work in factories, offices or other premises or in inter-State transportation and commerce including the training, supervision and qualification of such persons.'

Under Schedule IV, Item 2(c), one of the functions of a local government authority (municipal) is to facilitate 'provision and maintenance of health services' in section $2(\mathrm{c})$.

${ }^{6}$ Emphasis added. Section 1(1) (e) of the National Health Act 2014. The Act provides a framework for the regulation, development and management of a national health system and sets standards for rendering health services in the federation.

${ }^{7}$ Section 2(1) (i) of the National Health Act. This duty is vested in the Ministry of Justice.

${ }^{8}$ Section 4(1) of the Constitution provides that ' $\mathrm{t}$ ] he legislative powers of the Federal Republic of Nigeria shall be vested in a National Assembly for the Federation, which shall consist of a Senate and a House of Representatives.' Under section 4(4)(a), the National Assembly shall have power to make laws with respect 'any matter in the Concurrent Legislative List set out in the first column of Part II of the Second Schedule to this Constitution to the extent prescribed in the second column opposite thereto.' What this provision seems to suggest is that the National Assembly can make laws with regards to issues relating to health as stated in Schedule II, Part II, Item 17(a). It can be argued that the National Assembly has exercised its right under the Constitution to make access to healthcare a matter of rights as opposed to merely stating that healthcare is an aspirational objective and directive principle of the Nigerian government. 
respect, protect, enforce and promote the actualisation of human rights provisions including women's right to health, life and access to medicines as earlier enumerated. ${ }^{1}$ Nonetheless, the applicability of human rights provisions in international laws and instruments is not absolute. The binding obligation on the state to give practical expressions to the right to health and access to medicines as a constituent of the right in the international human rights instrument raises numerous enforcement issues particularly with regards to Section 12(1) of the Nigerian Constitution. Nigeria is a dualistic state; thus treaties and laws do not automatically carry the force of law. The reason for this is that Section 12(1) of the Constitution expressly provides that before a treaty can be recognised as law in Nigeria, it must be incorporated into national law by the National Assembly for domestic validity. ${ }^{2}$ At present, the UDHR, CEDAW, ICECSR and other international laws which contain significant human rights to health provision have not been enacted into the national laws of Nigeria. They will require domestication by the National Assembly to bear practical applicability and direct enforcement in Nigeria. The only binding human rights provision in Nigeria is the African Charter, which has been ratified and domesticated accordingly.

\subsubsection{Nigeria's Commitment and Obligation to the Right to Health in the African Charter}

At the regional level, Nigeria is a State Party to the African Charter. The Nigerian National Assembly in March 1983 formally incorporated the African Charter (Ratification and Enforcement) Act into the domestic laws of Nigeria. ${ }^{3}$ Section 1 of the Act states that the Charter

[s] hall have the force of law in Nigeria and shall be given full recognition and effort and be applied by all authorities. ${ }^{4}$

Thus the Act directly incorporates all the human rights provisions of the African Charter including the right to health. ${ }^{5}$ Furthermore, Article $18(3)$ of the Act specifically requires the state to take action to eliminate discrimination against women and ensure the protection of their rights as enumerated in international Declarations and Conventions including CEDAW. By virtue of the Act, all human rights provisions in the African Charter are recognised in Nigeria, hence the right to health in the Charter constitutes a part of the domestic laws of Nigeria. ${ }^{6}$ The policy makers, judiciary and legislature are therefore duty bound to enforce and safeguard the rights of every Nigerian to health. In this regard, Nigeria has an obligation to undertake all reasonable measures to guarantee the enjoyment of all human rights including the right to access medicines.

\subsubsection{What does this Human Rights Commitment mean for Women's Access to Medicines as a Right to Health in Nigeria?}

The explicit recognition of women's fundamental right to health imposes a duty on the Nigerian state to give serious considerations to women's state of health in Nigeria and also to promote, protect, and provide adequate, affordable medicines in this respect. The state has a duty to guarantee that there is no impediment to this access, including ensuring that its activities or those of third parties, laws and treaty obligations are not inconsistent with its human rights duties to health. The failure of the Nigerian state to promote, respect and fulfil its obligations to women's rights means that it is in breach of its duty. The African Charter has played an important role in imposing a human rights responsibility on the Nigerian government to respect the right to health and provide medical care to its citizens. In Media Rights Agenda \& Others v Nigeria, the Commission took the view that the denial of an incarcerated suspect's access to medical care while his health was deteriorating is a clear violation of the right to health under Article 16 of the Charter. ${ }^{7}$

\footnotetext{
${ }^{1}$ See the analyses in subsections $1.2 .3,1.2 .4,1.2 .5,1.3$ and 1.4 of this chapter.

${ }^{2}$ Section $12(1)$ provides that

[n]o treaty between the Federation and any other country shall have the force of law to the extent to which any such treaty has been enacted into law by the National Assembly.

What this means is that international law does not exist as law unless it is explicitly incorporated into national law as well. Section 12(2)(3) of the Constitution further provides that where the subject matter of a treaty falls outside the Exclusive Legislative List, a bill for an Act of the National Assembly to give the treaty the force of law must be ratified by a majority of all the Houses of Assembly in the federation before it is enacted and assented to by the President. Hence, until a treaty has been domesticated in Nigeria, it cannot be applied within the country. ${ }^{3}$ This Charter is part of the Nigerian law in Chapter 10 Laws of the Federation 1990. (It is worth noting that, although the National Assembly enacted the Act in 1983, the president was entrusted with the power to set the commencement date for the Act. Before the date was set, the military Administration took over. Consequently, the Revised Edition of the Laws of the Federation of Nigeria backdates the Act and its commencement to 17 March 1983.)

Nnamuchi (n 30) 16; U Umozuruike The African Charter on Human and Peoples' Rights (Kluwer Law International 1997) 111.

${ }^{4}$ Section 1 of the Act. Paragraph 3(a) of the Preamble to the Fundamental Rights (Enforcement Procedure) Rules 2009 further clarified that ' [ $[$ ] he Constitution, especially Chapter IV, as well as the African Charter, shall be expansively and purposely interpreted and applied, with a view to advancing and realising the rights and freedoms contained in them and affording the protections intended by them.'

${ }^{5}$ By virtue of Article 16 of the African Charter on Human and Peoples' Rights (Ratification and Enforcement) Act Chapter A9 which states that:

Every individual shall have the right to enjoy the best attainable state of physical and mental health.

${ }^{6}$ Furthermore, in Order 1 (2) of the Fundamental Rights (Enforcement Procedure) Rules, 2009 'Fundamental Right' is defined as 'any of the rights provided for in Chapter IV of the Constitution, and includes any of the rights stipulated in the African Charter on Human and Peoples' Rights (Ratification and Enforcement) Act.'

${ }^{7}$ Media Rights Agenda and Others v Nigeria (2000) AHRLR 200 (ACHPR 1998) paragraphs 90, 91. Likewise, the Commission considered it a violation of the right to health under Article 16 to deprive prisoners of food, blankets and adequate hygiene as it affected their general state
} 
With specific regard to international human rights instruments such as ICECSR and CEDAW, containing important human rights obligations to health, the interpretative authority of the CECSR remains unclear since Nigeria is yet to incorporate the Covenants. ${ }^{1}$ Interestingly however, Article 60 of the African Charter provides that the Commission 'shall draw inspiration from international law on human rights and people's rights,' including the provisions of ICESCR on rights to healthcare, and 'specialised agencies of the United Nations' such as the CECSR which has clearly stated that access to medicines is a constituent component of the right to health. ${ }^{2}$ In light of this provision, it appears that the provisions of the ICESCR and the accompanying General Comments and recommendations on the right to health can provide a conceptual interpretation and also guide the courts in the adjudication of rights of women and every Nigerian citizen's to access medicines as a fundamental human right. Likewise General Comment No 2 on Article 14(1)(a)(b)(c) and (f) and Article 14(2)(a) and (c) of the Protocol to the African Charter on Human and Peoples' Rights on the Rights of Women in Africa provides similar principles in relation to the right to health and the analogous state obligations as contained in CEDAW General Recommendation on Women's Right to Health. ${ }^{3}$ It can be said, therefore, that attaining the best standards of health of women in Nigeria will require access to medicines to overcome illnesses and restore health. This also requires the state to address violations and safeguard against interference by patent right holders and pharmaceutical companies. Section 16(2) of the African Charter (Ratification and Enforcement) Act specifically mandates the state to protect the health of the people and ensure access to medical care. Access in this regard presupposes that the Nigerian government should take all necessary actions, including the use of patents exceptions and TRIPS-complaint flexibilities safeguards to provide essential medicines and also ensure that accessibility to the medicine is not hindered. ${ }^{4}$

A question with regards to the African Charter, however, is whether it has domestic application in terms of the enforcement of its provisions by the courts in Nigeria. In a number of cases, the courts have held that the African Charter and all its provisions are indeed directly enforceable in Nigeria. In Ogugu \& others $v$ State, ${ }^{5}$ the Supreme Court held per Bello (CJN) that the African Charter is a part of Nigeria's domestic law as '[...] the Charter has become part of our domestic laws, the enforcement of its provisions like our laws fall within the judicial powers of the Court as provided by the Constitution and all other laws relating thereto. ${ }^{6}$ Accordingly, the rights in the African Charter are '[...] enforceable by the several High Courts depending on the circumstances of each case and in accordance with the rules, practice and procedure of each Court. ${ }^{7}$ Thus all human rights provisions including the right to health in the African Charter are justiciable and applicable in all courts of law in the same manner as the Fundamental Rights in Chapter IV of the Constitution. ${ }^{8}$ This opinion is supported by Cui who notes that the Nigerians can rely on the African Charter as an enforceable legal instrument, to seek redress for their human rights. ${ }^{9}$ This position is also reiterated by the Supreme Court in General Sani Abacha \& 3 others $v$ Gani Fawehinmi. ${ }^{10}$ The Supreme Court held that the African Charter is a part of Nigerian laws and the provisions are enforceable by the courts as other laws in Nigeria. It follows that the right to the

of health. See Thirteenth Annual Activity Report of the African Commission on Human and Peoples' Rights 1999 - 2000158.

${ }^{1}$ Nonetheless, the provisions of the African Charter and Protocol to the African Charter on Human and Peoples' Rights on the Rights of Women in Africa with respect to their right to health can be legitimately enforced by the courts in Nigeria.

${ }^{2}$ As articulated in subsection 4.2.4.

${ }^{3}$ And also, African Commission on Human and Peoples' Rights, General Comment No. 3 on the African Charter on Human and Peoples' Rights: The Right to Life (Article 4) (Adopted during the 57th Ordinary Session of the African Commission on Human and Peoples' Rights held from 4 to 18 November 2015 in Banjul, The Gambia) Paragraphs 3, 42 and 43 where state's obligation to the right to life is broadly construed to include adequate healthcare. In paragraph 42, the state has an obligation to prevent maternal mortality 'by establishing functioning health systems and

eliminating discriminatory laws and practices which impact on individuals' and groups' ability to seek healthcare.'

${ }^{4}$ Within the context of promoting the right to health, scholars have pointed out that compulsory licence and other public health exemptions are valuable tools for this purpose. See Zita Lazzarini, 'Making Access to Pharmaceuticals a Reality: Legal Options under TRIPS and the Case of Brazil' (2003) 6(1) Yale Human Rights and Development Law Journal 103, 125; Haochen Sun, 'A Wider Access to Patented Drugs under the TRIPS Agreement' (2003) 21 Boston University International Law Journal 101. (Sun argues for the implementation and interpretation of the TRIPS flexibilities, Doha Declaration and the Paragraph 6 Solution in light of public policies and the right to health, particularly, accessibility, availability and affordability in a non-discriminatory manner, to secure access to medicines.) ibid 112-113.

${ }^{5}$ Ogudu v State (1994) 9 NWLR (Pt.366) 1. (The case is also reported as Peter Nemi v A.G of Lagos [1994]1LRC 376 in some reports.) In this case, the 3rd appellant and four other persons were convicted of conspiracy to commit armed robbery and sentenced to death on 28 th February 1986. In their appeal, they invoked the provisions of the African Charter and invited the court to assume jurisdiction in a question of complaint of "cruel, inhuman or degrading punishment and treatment" contrary to Article 5 of the African Charter on Human and Peoples Right.

6 ibid 26-27, paragraph G-G ibid.

${ }^{7} 27$, paragraph G-G ibid.

${ }^{8}$ What this signifies is that all the provisions of the Charter will have similar effects to the Fundamental Rights under the Constitution. Olowu (n 307) 173. Although this was decided based on the enforcement of a civil and political right, undoubtedly, the application of the Court's decision extends to the socio-economic rights in the Charter.

${ }^{9}$ Roberto Cui, Oil Multinationals in Nigeria: Human Rights, Sustainable Development and the Law (Anchor Academic Publishing (Aap Verlag) 2015) 54.

${ }^{10}$ (2000) Volume 4 Federation Weekly Law Reports 533. In this case, the respondents challenged their detention by the military government on the grounds that it violated their fundamental human rights under the Nigerian Constitution and Article 4, 5, 6, 12 of the African Charter. 
'best attainable standard of mental and physical health' including access to medicines in the Charter can be enforced by the courts in Nigeria. ${ }^{1}$ Importantly therefore, the right to health in the African Charter complements the absence of an enforceable right to health in the Constitution. ${ }^{2}$

This argument finds support in the seminal ruling by the African Commission on Human and People's Rights in Social and Economic Rights Action Centre (SERAC) and another v Nigeria. ${ }^{3}$ The Commission broadly interpreted the African Charter to enforce the right to health provisions amongst others, and found that the Federal Republic of Nigeria was in violation of Articles 2, 4, 14, 16, 18 (1), 21 and 24 of the African Charter on Human and Peoples' Rights by allowing multi-national companies to carry out oil exploration operations that affected the environment and health of the people in that region. ${ }^{4}$ The Commission imposed a responsibility on the Nigerian government to respect the health and environmental rights of the people of Ogoniland, even though it was a non-justiciable right under the Nigerian Constitution. This decision opened up another avenue for the enforcement of the right to health in Nigeria. Fundamentally, this was a decision against acts committed by a corporation but the court held the Nigerian government liable for the acts of the third parties. Applying the current understanding of the obligations of pharmaceutical corporations to respect and promote rights to health and access to medicines, there is no reason barring the application of the court's rationale in this case to determine the liabilities and responsibilities of pharmaceutical companies in cases on pharmaceutical patents and access to medicines.

Nevertheless, Section 12(1) of the 1999 Constitution remains in force; hence CEDAW, ICECSR and UDHR which contain significant human rights to health provisions, will require domestication to bear meaningful practical applicability in Nigeria. In the meanwhile, the binding duty of responsibility on the Nigerian government to give reference to the provision of adequate healthcare and medicines in the African Charter and Constitution is sufficient to compel a binding duty. As Article 5(3) of the Protocol to the African Charter allows relevant NGO's with observers status and Individuals to institute cases directly to the African Commission with regards to their human rights, Nigerians and NGO's on their behalf can institute actions to mandate the government to foster better access to medicines as a part of the people's legitimate human rights entitlements. Nigerians can also seek to compel the government to take into account the human rights aspirations and interests of the people in the negotiations, implementation and enforcement of its international trade obligations such as TRIPS. More specifically, the government can be mandated to consider the citizens' rights to health when designing, structuring and enforcing the rights and exceptions contained in its patent law.

\subsubsection{Adopting a Rights-Based Approach to Patent Right to Promote Women's Right to Access Medicines in Nigeria}

The sum total of the arguments and analysis indicates that human rights relate to health and that access to medicines is germane to the enjoyment of the right to health as well as the right to life. In this manner, human rights provide the basis to argue for the alleviation of problems inhibiting women's access to healthcare in Nigeria. This rights approach to the issue of accessing medicine is relevant because it provides a guiding standard for national policies, laws and programmes to achieve the goal of fulfilling, protecting, respecting and generally securing their right to health.

To secure women's right to health and ensure that they can fully enjoy their human rights, it is submitted that there is a need to promote their access to affordable medicines. The article highlighted the concern that the patent protection of pharmaceuticals could result in high prices or stifle incremental innovation which could have the effect of impeding the availability of and women's access to affordable drugs for serious medical needs. In this event, one of the ways in which the Nigerian state can meet its obligation, as to the right to health is to make sure that pharmaceutical patents do not constitute an obstruction to the enjoyment of the rights of women to better healthcare.

From a health perspective, however, patents cannot be discounted. Patent, as has been argued, could promote public health by facilitating increased medicinal R\&D. Thus the human rights perspective in this study does not reject the importance of protecting the interests of the pharmaceuticals industry and patent right owners with regards to their pharmaceutical patent rights. However, there is a need for the Nigerian state to balance its

\footnotetext{
${ }^{1}$ Per Ogundare JSC (ibid 31-32, paragraph F-G). Notwithstanding this, the court held that the Constitution is supreme and overrides any other law or binding international treaties; hence in the event of a contravening provision in the Charter, the Constitution will prevail.

${ }^{2}$ In Socio-Economic Rights and Accountability Project (SERAP) v Federal Republic of Nigeria and Universal Basic Education Commission (2012) No. ECW/CCJ/APP/0808, the Economic Community of West African States (ECOWAS) Community Court of Justice also upheld the justiciability of the African Charter as a part of the domestic laws in Nigeria. In a case involving the right to education, the court held that it has the jurisdiction to entertain matters under the African Charter notwithstanding the fact that the educational objective in the Constitution of Nigeria is unenforceable by the court. The court ruled that 'under article 9 (4) of the Supplementary Protocol, the Court clearly has jurisdiction to adjudicate on applications concerning the violation of human rights that occur in Member States of ECOWAS' and that it 'has jurisdiction over human rights enshrined in the African Charter and the fact that these rights are domesticated in the municipal law of Nigeria cannot oust the jurisdiction of the Court.'

${ }^{3}$ (2001) Communication No 155/96 African Commission on Human and Rights (ACHPR)

${ }^{4}$ See ibid paragraph 70 .
} 
responsibilities to women's human rights and promoting scientific and medicinal R\&D. One way of so doing is to limit the impact of patent rights on human rights in national laws. The state can do this by relying on public interest measures and flexibilities in the TRIPS Agreement to broadly give effect to the right to health and access to essential drugs. ${ }^{1}$ The right of WTO members to determine their appropriate level of protection in a given situation has been recognised by the WTO appellant body. ${ }^{2}$

Another possibility open to the Nigerian government and the national courts is to strike a balance between the human rights-related interest of inventors on the one hand and promoting society's welfare (which includes women's rights) to access the fruits of pharmaceuticals R\&D on the other. The need to strike a balance between the rights of the creators and the human right to access the products of technological innovation such as medicines also mirrors the debate about the balance of patent holders' rights and user's rights in IP systems. It is commonly argued that an objective of patent protection is to promote long-term public interest and social welfare by means of providing exclusive rights to right holders for a limited duration. ${ }^{3}$ During the term of protection, there is potential for conflict between these private and public rights considerations, which can also mirror the differences between the interests of right holders and end users under human rights law. The challenge for national and international lawmakers is to find the optimal balance between the various competing interests with a view to maximising the benefit of the invention to the public, whilst also meeting the private interests of inventors. ${ }^{4}$

One way in which this can be done is by properly delineating the nature and scope of public and private rights. For patents, the patentable subject matter, scope, limitations and term of protection, can be clearly defined and balanced against the socio-economic and cultural rights such as rights to health. Also, a way of finding this balance might be to clearly map out the purpose of patents, which is the promotion of technological and social development, and state that where private rights interfere with this goal, the fundamental human rights to health should prevail in the public interest. Human rights law does not provide a clear indication on how to strike the right balance between protecting the interests of inventors and promoting access to the products of intellectual activities, neither do international IP agreements offer an ideal balance. However, within the context of patent law, states can clearly delineate a way of addressing these two interests when they conflict. There is no Nigerian jurisprudence to support this point, however, by way of example, the case of Smith Kline and French Laboratories Ltd $v$ Netherlands buttressed the point that public interest is given paramount importance where there is a conflict of interests. ${ }^{5}$ The ECHR stated that the granting of compulsory licensing for a patented drug was not an interference with the human rights entitlement under Article 1 of Protocol No 1 of the ECHR. ${ }^{6}$ Even when the patent holder's right was recognised as a human right, the court gave primacy to the public interest.

In that case, the applicant, a proprietor of a patented medicine cimetidine (for the treatment of gastric and duodenal ulcer), appealed against the granting of a compulsory license to a drug company, Centrafarm Bv, to use and work whose patented invention. Among other things, the applicant claimed that the compulsory licence was a violation of its right to peaceful enjoyment of its 'possession' contrary to Article 1(1) Protocol 1, and that the licence interfered with the exclusive right to exploit the patented invention. ${ }^{7}$ The ECHR in its ruling found that, although the compulsory license 'constitutes a control of the use of property,' the grant was lawful in accordance with the general interest of the public. ${ }^{8}$ Notably, the general public interest was adopted as a yardstick by the courts to test whether the interference with the use and enjoyment of the proprietor's right was lawful. In the end, the ECHR came to the conclusion that, 'the grant of the compulsory licence was lawful and pursued a legitimate aim of encouraging technological and economic development.' ${ }^{9}$ Since the applicant's invention prevented the working of a patent that that was beneficial to society, the ECHR considered the long-term interest of the public to benefit from technological and scientific progress to decide in favour of the compulsory licence.

It could be said that the interests of the patentee, in this case, were recognised; hence the ECHR found that

\footnotetext{
${ }^{1}$ See the case of Novartis AG v Union of India. IPAB Order No 100/2009 available at <http://www.ipab.tn.nic.in/Orders/100-2009.htm> accessed 22 October 2013; see also SC Civil Appeal Nos. 2706-2716 of 2013, paragraph 168.

${ }^{2}$ Accordingly, 'WTO Members have a right to determine the level of protection of health that they consider appropriate in a given situation'. European Communities - Measures Affecting Asbestos and Asbestos-Containing Products: Appellate Body Report (WT/DS135/AB/R April 5 2001) 168 .

${ }^{3}$ Margaret Chon 'Substantive Equality in International Intellectual Property Norm-Setting and Interpretation' in Daniel Gervais (eds), Intellectual Property, Trade and Development: Strategies to Optimize Economic Development in a TRIPS-Plus Era (OUP Oxford 2007) 476. For example, Lord Oliver in the United Kingdom (UK) case of Asahi Kasei Kogyo KK's Application aptly captured this objective thus: The underlying purpose of the patent system is the encouragement of improvements and innovation. In return for making known his improvement to the public the inventor receives the benefits of a period of monopoly during which he becomes entitled to prevent others from performing his invention except by his licence. Asahi Kasei Kogyo KK's Application [1991] RPC 485 (HL)

${ }^{4}$ Laurence R Helfer, 'Human Rights and Intellectual Property: Conflict or Coexistence?' (2003) 5 Minnesota Intellectual Property Review 47, 47-49.

${ }^{5}$ SmithKline and French Laboratories Ltd v Netherlands Application 12633/87, (1990) ECHR Decision and Reports.

${ }^{6}$ ibid

7 ibid paragraph 2 .

8 ibid

${ }^{9}$ ibid
} 
the decision of the patent office to grant the licence constituted an interference with the inventor's rights and use of its property. Yet, the ECHR took into account the broader development goal of the public (the dependent patent in this case) to access and use the patented invention since it was clear that the applicant's patent limited the use and working of Centrafarm Bv's invention. The ECHR attempted to strike a balance between two competing interests (SmithKline and French Laboratories Ltd and Centrafarm Bv) by recognising the overall objective of encouraging technological and economic development as a yardstick to measure their various interests.

In another example, the Indian Supreme Court in 2014, dismissed a petition by Bayer to set aside the compulsory license on the anti-cancer drug 'Sorafenib Tosylate', otherwise marketed as 'Nexavar.' In that case, Nacto Pharma Ltd., a pharmaceutical drug producer, made a request for a voluntary licence to Bayer which was denied. Natco subsequently made an application for, and was granted, a compulsory licence to manufacture and market the patented drug in 2011. On appeal by Bayer against the decision to grant the compulsory licence, Natco argued in defence that Sorafenib tosylate, a crucial drug for patients living with kidney and liver cancer, was unreasonably expensive and unaffordable to patients in India. Moreover, Bayer had not worked its drug, Nexavar, in the territory of India. Bayer contended these claims, but the Controller General of Patents ruled in favour of Natco. ${ }^{2}$ In 2013, the Intellectual Property Appellate Board (IPAB) considered whether the licence can be granted to the applicant on the grounds that the drug was not 'available to the public at a reasonable price' in accordance with Section 84(1)(b) of Indian Patents Act. The IPAB after a careful deliberation, dismissed the appeal filed by Bayer and confirmed the compulsory licence given to Natco. ${ }^{3}$ The IPAB based its decision on the yardstick of the public in ruling that ' $[$ s]ection $84[\ldots]$ is only concerned with the price at which the drug is made to the public.' ${ }^{4}$ Significantly, the IPAB approached the appeal from the perspective of the public interest within the context of the right to life as guaranteed under Article 21 of the Constitution of India, 1950. Accordingly,

[t]here we are not concerned with the interest of the compulsory licence applicant, but only the public interest. The grant of compulsory licence is not to favour the applicant, but only because the applicant has demonstrated that the invention has not reached the public in the manner envisaged under Section $84 .^{5}$

The ruling in this case upheld the primary importance of public health over private monopoly rights and gave impetus for the Indian Government to grant more compulsory licences in the interest of access to medicines.

Commentators have also pointed to the persuasive effect of human rights rhetoric as a means to balance the rights in IP laws, mitigating the adverse impact of IP rights or adjusting IPRs to respond to essential human rights needs. ${ }^{6}$ For example, Professor Correa points out the variety of ways that Human Rights Impacts Assessments (HRIAS) have been used to assess the direct and indirect impacts of agreements, treaties, and actions which affect the right to health. ${ }^{7}$ Likewise, he examined the role and use of human rights principles by the courts to mitigate the excessive effect of IP on access to medicines and rights to health and concludes that human rights values, when incorporated into national legal systems, can 'provide national Courts with grounds for effectively circumscribing the substantive procedural rights conferred under different modalities of IPR." Also, that there is 'a lot of promise for the potential of human right [to health] arguments to play a key role in

\footnotetext{
1 Further information is available at 'Breaking News!! SC Dismisses Bayer's SLP Against India's First CL' (Spicy IP) $<$ http://spicyip.com/2014/12/breaking-news-sc-dismisses-bayers-slp-against-indias-first-cl.html> accessed April 23, 2016; 'Supreme Court Says No to Bayer, Upholds Compulsory License on Nexavar' (Lawyerscollective.org)

$<$ http://www.lawyerscollective.org/updates/supreme-court-says-no-to-bayer-upholds-compulsory-license-on-nexavar.html $>$ accessed 23 April 2016.

${ }^{2}$ See decision of the Controller at Natco Pharma Ltd v Bayer Corporation - Application for Compulsory License under Section 84(1) of the Patents Act 1970 in respect of Patent No 215758 Controller General of Patents, Mumbai, CLA No 1 of 2011 (unreported) also available at http://www.ipindia.nic.in/iponew/compulsory license 12032012.pdf. After a careful consideration of evidence, the Controller General came to the conclusion that the patented invention was not 'available to the public at a reasonably affordable price' not locally manufactured in India, and that the patent rights holder has 'failed to grant a voluntary license on reasonable terms to anyone,' therefore, a compulsory licence was granted to Natco Pharma Ltd. The licence effectively authorises Natco Pharma Ltd to produce the drug in its own facilities and sell it. A royalty payment of six percent is to be paid to Bayer Corporation. Natco Pharma Ltd v Bayer Corporation Controller General of Patents, Mumbai, CLA No 1 of 2011. 35-61 (unreported)

See also Charles Lawson, 'Accessing and Affording Drugs Despite the Patent Barrier: Compulsory Licensing and Like Arrangements?' (2013) 24 AIPJ 94, 107-108; Mansi Sood, 'Natco Pharma Ltd. V. Bayer Corporation and the Compulsory Licensing Regime in India' [2013] NUJS Law Review, 104.

${ }^{3}$ Bayer Corporation v Natco Pharma Ltd., Order No. 45/2013 (Intellectual Property Appellate Board, Chennai).

${ }^{4}$ ibid paragraph 42 .

${ }^{5}$ ibid paragraph 43

${ }^{6}$ Laurence R Helfer, 'Toward a Human Rights Framework For Intellectual Property' (2007) 40972 University of California Davis Law review 971, 976

${ }^{7}$ Carlos M Correa, 'Mitigating the Impact of Intellectual Property in Developing Countries Through the Implementation of Human Rights' in Christophe Geiger (ed), Research Handbook on Human Rights and Intellectual Property (Edward Elgar Publishing 2015) 208-210.

One example he gave was the assessment of the effect of IPRs on rights to health in the Central American Free Trade Agreement (CFTA) by the Defensoria de los Habitantes de la Republica of Costa. ibid 209.

8 ibid 216.
} 
judicial decision-making. ${ }^{\prime 1}$

Furthermore, it is submitted that the courts can adopt a rights-based approach to interpret and enforce matters bordering on patents and rights to health, life and the dignity of the human person. In recent times, a number of national court decisions in other jurisdictions have provided clear reference points on the impact of, and relationship between access to medicines, human rights and IPRs in general. For example, adopting a rightsbased approach, the Kenyan Courts recognised the precedence of public health and basics human health over private IP rights in Patricia Asero Ochieng, Maurine Atieno, Joseph Munyi, and AIDS Law Project v. Attorney General. $^{2}$ The court stated that the "right to life, dignity and health of the petitioners must take precedence over the intellectual property rights of patent holders. ${ }^{3}$ In that case, a group of individuals living with HIV/AIDS instituted an action, challenging the Kenya Anti-Counterfeit Act on the grounds that the counterfeit provisions which included essential generic medications as counterfeit goods, violated their ability to access affordable and generic medicines and, therefore, their rights to health. The court, in ruling that IPRs should not override essential rights to life and health, found that the sections ${ }^{4}$ would negatively impact on the rights of the petitioners and others living with HIV and [AIDS] to access essential medicines. ${ }^{5}$ Thus, the Act was in "violation of their rights under the [Kenyan] constitution. ${ }^{6}$ Although the public policy objective of the Act was to prohibit counterfeit goods, the court took into account the effect of the provisions on the petitioners' access to available and affordable essential medicines, including generic drugs. ${ }^{7}$ Importantly, this case supports the position adopted that the right to access affordable essential medicines is greater and more critical than the enforcement of IP rights. $^{8}$

The Indian case of F. Hoffmann-La Roche Ltd. and Anr. v Cipla Ltd, further illustrates the point that litigation can effectively be used to give consideration to the rights to access affordable essential life-saving drugs where patent rights adversely impact on rights to medicines. ${ }^{9}$ In this case, the plaintiff brought an action against the generic producer, Cipla Ltd, to prevent the infringement of its patent rights to the cancer drug erlotinib hydrochloride ('Tarceva'). In a landmark decision, the court, in refusing the interim order sought by the plaintiff, also based its decision on broader public interest, health and the right to access life-saving medicines. ${ }^{10}$ In this connection, the court ruled that although,

India entered into the TRIPS regime, and amended her laws to fulfil her international obligations,

$[\ldots]$ the Court cannot be unmindful of the right of the general public to access lifesaving drugs which are available and for which such access would be denied if the injunction were granted. The degree of harm in such eventuality is absolute; the chances of improvement of life expectancy; even chances of recovery in some cases would be snuffed out altogether, if injunction were granted. ${ }^{11}$

It is worth noting that the patent protected version of the drug in this case cost three times the price of the generic version by Cipla. ${ }^{12}$ Deciding in favour of the defendant meant that general public interest had a greater weight than private proprietary interest. In the end, the judicial decision was useful to safeguard the rights of the

\footnotetext{
${ }^{1}$ ibid 216.

${ }^{2}$ Petition No.409, 2009 paragraph 56. (The Judge ruled that the right to health, life and human dignity are inextricably bound; there can be no argument that 'without health, the right to life is in jeopardy [...].'

${ }^{3}$ Paragraph 85 of the court's decision ibid.

${ }^{4}$ Sections 2, (definition of counterfeiting) section 32 (offences) and section 34 (powers of commissioner to seize suspected counterfeit goods).

${ }_{5}^{5}$ For the full judgment, see <kelinkenya.org/wp-content/uploads/2010/10/Judgment-Petition-No-409-of-2009-Anti-counterfeit-case.pdf> accessed 14 July 2015.

${ }^{6}$ The Court relied on the constitutional human rights of the petitioners to human dignity and highest standard of health as protected under Articles 26(1), 28 and 48 of the Constitution to make the order. Paragraph 52 of the decision.

More discussions on the case at Allan Maleche and Emma Day, 'Right to Health Encompasses Right to Access Essential Generic Medicines: Challenging the 2008 Anti-Counterfeit Act in Kenya' (2014) 16(2) Health Human Rights 96.

${ }^{7}$ Paragraph 52 of the decision.

${ }^{8}$ Paragraph 85 of the decision.

9148 (2008) DLT 598, MIPR 2008 (2) 35. Judgment delivered by J Ravindra Bhat.

${ }^{10}$ Similarly, in the 2013 copyright related case of Ediciones de la Flor SA v. Fontanarrosa Franco s. Acción Mere Declarativa, file no. 1420/08, the Court of First Instance on Civil and Commercial Matters No. 12 of Rosario, the co-heir of a deceased author, Roberto Fontanarrosa, opposed the publication of the deceased's unpublished works (a moral right specifically recognized to the author) arguing subsidiary moral rights as co-heir. The Argentinian Court of First Instance in Civil and Commercial Matters (No. 12 of Rosario) held that the rights of the public or community interest to have access to the unpublished work will prevail over authorial economic and moral interest, thus ensuring that social interests superseded individual private IP rights. In its decision, the court relied on Article 21(1) of the American Convention of Human Rights (which states that '[e]veryone has the right to the use and enjoyment of his property. The law may subordinate such use and enjoyment to the interest of society.'), and Article 15(1) (a) of the International Covenant on Economic, Social and Cultural Rights

See the translated report in Maximiliano Marzetti, ' Comments on Ediciones De La Flor v Fontanarrosa Franco' (2013) 44(7) International Review of Industrial Property and Copyright Law

${ }^{11}$ Paragraph 85 of the decision. An appeal against this decision found that there was no infringement.

${ }^{12}$ Carlos M Correa, 'Mitigating the Impact of Intellectual Property in Developing Countries Through the Implementation of Human Rights' in Christophe Geiger (ed), Research Handbook on Human Rights and Intellectual Property (Edward Elgar Publishing 2015 ) 212.
} 
public to access essential drugs. ${ }^{1}$

The cases above lend credence to the point that national courts can adopt standards of interpretation to give significant effect to human rights to health in view of the public interest and welfare. To fully implement the right to health, and particularly women's rights to access medicines with regards to patent rights, the Nigerian courts can play a major role. In actions bordering on health and access to medicines, the courts can interpret and lay down similar human rights standards for the guarantee and enforcement of health provisions. It has been argued that national courts can play a role in giving practical effect to human rights by preventing violation and interference. ${ }^{2}$ The courts can also encourage and where necessary, compel the fulfilment and realisation of human rights. ${ }^{3}$ Since human rights are part of the legal framework of Nigeria as per the African Charter, the courts could develop appropriate standards for enforcing the right to health and life, particularly where the issues concern the conflict between public health and patent rights. The principles of human rights and key dimensions of the right to health provide a fundamental jurisprudence to guide the court in this duty to enhance women's rights to health in Nigeria.

\subsection{Conclusion: Making Human Rights Central to Promoting Women's Access to Medicines within the Context of Patent Rights in Nigeria}

Indubitably, everyone is entitled to the right to a standard of health. While women's rights to health and life are clearly established in legal instruments, having these laws without the fulfilling them will not serve the people they are meant to safeguard. For this reason, this study argues that the right to health and life includes the right to an effective access to available, good quality, safe, and effective medicines that are equally affordable to everyone. It is also submitted that ensuring this access to a choice of essential medicines at an affordable price requires the state to ensure that the granting of patent rights to inventors and pharmaceutical companies does not hinder access to essential drugs.

More specifically, the argument based on human rights principles is a consideration of women's health needs in Nigerian regulations and policies to fulfil their demands of healthcare. Although the current effect of international human rights laws in Nigeria with regards to Section 12 of the 1999 Nigerian Constitution leaves many of questions open, the government is not absolved of its socio-economic and cultural obligations to promote, respect and fulfil the rights of women to have equal access to affordable, safe and effective medicines. This positive step in the right direction includes implementing the TRIPS Agreement in a manner that supports women's rights to health. Such a trade agreement should be balanced against the right to health, especially where its patent rights interfere with health of women whether directly or indirectly. ${ }^{4}$

More research is needed to improve the prediction of how pharmaceutical patents affects women in particular, with more effective implementation of preventative measures. The author also emphasises the need for a thorough investigation of whether and how the patent exemptions and TRIPS flexibilities can ameliorate the issue of access to medicines in Nigeria and other developing countries.

\section{Bibliography}

'Breaking News!! SC Dismisses Bayer's SLP Against India's First CL' (Spicy IP) $<$ http://spicyip.com/2014/12/breaking-news-sc-dismisses-bayers-slp-against-indias-first-cl.html >

Adewole v Jakande (1981) 1 N.C.L.R. 152.

African Charter on Human and Peoples' Rights (African Charter) (Nairobi, 27 June 1981, entered into force 21 October 1986, 1520 UNTS 217) (Banjul Charter) (Hereinafter African Charter)

African Commission on Human and Peoples' Rights, General Comment No. 3 on the African Charter on Human and Peoples' Rights: The Right to Life (Article 4) (Adopted during the 57th Ordinary Session of the African Commission on Human and Peoples' Rights held from 4 to 18 November 2015 in Banjul, The Gambia)

Agbakoba $\mathrm{O}$ et al., Towards a Peoples' Constitution in Nigeria: A Civic Education Manual for the Legal Community (Human Rights Law Service 2002).

Akande J.O.D., The Constitution of the Federal Republic Of Nigeria, 1979: With Annotations (Sweet \& Maxwell 1982)

\footnotetext{
${ }^{1}$ The obligation of the state to protect rights to health and life was also reiterated in the case of Eli Lilly and Company v Laboratorios Leti, S.A.V. y otra s/ Infracción de derechos (patente) (2011) Circunscripción Judicial of Caracas, Venezuela,Juzgado Superior Octavo en lo Civil, Mercantil, Tránsito y Bancario. [Judicial Circuit of Caracas, Venezuela, Eight High Tribunal on Civil, Commercial, Transit and Banking]. In that case, the defendant alleged that the act of granting marketing approval of the medicine raloxifen hydrochlorid, before the expiration of its patented term was an infringement of patent rights. The court stated that 'the right to health as an integral part of the right to life, in keeping with the high aim of the Andean integration, represents an obligation for the state.' (As interpreted and quoted in Correa (n 393) 214 .) ${ }^{2}$ Cnthia Soohoo and Jordan Goldberg, 'The Full Realization of Our Rights: The Right to Health in State Constitutions' (2010) 60(4) Case Western Reserve Law Review 997, 1072.

${ }^{3}$ ibid

${ }^{4}$ Nigeria has not incorporated the Agreement as required under Section 12 of the Constitution.
} 
Akintayo A.E, 'A Good Thing from Nazareth? Stemming the Tide of Neo-Liberalism Against Socio-Economic Rights: Lessons from the Nigerian Case of Bamidele Aturu v Minister of Petroleum Resources and Others' (2014) 15(2) ESR Review.

Archbishop Anthony Olubunmi Okogie (Trustee of Roman Catholic Schools) \& Others vs Attorney General of Lagos State (1981) 2 NCLR 350.

Asahi Kasei Kogyo KK's Application [1991] RPC 485 (HL)

Attorney General of Ondo State v Attorney General of the Federation \& Others (2002) 9 NWLR (Pt 772)

Attorney-General of Ondo State v Attorney-General of the Federation (2002) FWLR (pt. 111) Ajigboye O, 'Realization of Health Right in Nigeria: A Case for Judicial Activism' (2014) 14(3) Global Journal of Human Social Science Research 23.

Bamidele Aturu v Minister of Petroleum Resources and Others (2013) Suit No FHC/ABJ/CS/591/09,

Bayer Corporation v Natco Pharma Ltd., Order No. 45/2013 (Intellectual Property Appellate Board, Chennai).

Chon M., 'Substantive Equality in International Intellectual Property Norm-Setting and Interpretation' in Daniel Gervais (eds), Intellectual Property, Trade and Development: Strategies to Optimize Economic Development in a TRIPS-Plus Era (OUP Oxford 2007)

Constitution of Federal Republic of Nigeria 1999 Cap. C23 Laws of Federation of Nigeria 2004.

Controller at Natco Pharma Ltd v Bayer Corporation - Application for Compulsory License under Section 84(1) of the Patents Act 1970 in respect of Patent No 215758 Controller General of Patents, Mumbai, CLA No 1 of 2011 (unreported) also available at http://www.ipindia.nic.in/iponew/compulsory_license_12032012.pdf.

Cook J.R., Women's Health and Human Rights (World Health Organization 1994).

Correa M. C., 'Mitigating the Impact of Intellectual Property in Developing Countries Through the Implementation of Human Rights' in Christophe Geiger (ed), Research Handbook on Human Rights and Intellectual Property (Edward Elgar Publishing 2015).

Correa M.C., 'Mitigating the Impact of Intellectual Property in Developing Countries Through the Implementation of Human Rights' in Christophe Geiger (ed), Research Handbook on Human Rights and Intellectual Property (Edward Elgar Publishing 2015)

Cui R., Oil Multinationals in Nigeria: Human Rights, Sustainable Development and the Law (Anchor Academic Publishing (Aap Verlag) 2015).

Desai M and Chand D., 'Fundamental Right to Health and Public Health Care' in Mihir Desai and Kamayani Bali Mahabal (eds), Health Care Case Law in India (Centre for Enquiry into Health and Allied Themes (CEHAT) and India Centre for Human Rights \& Law (ICHRL) 2007)

Durojaiye E., 'Litigating the Right to Health in Nigeria: Challenges and Prospects' in Magnus Killander (ed), International Law and Domestic Human Rights Litigation in Africa (PULP 2010)

Ediciones de la Flor SA v. Fontanarrosa Franco s. Acción Mere Declarativa, file no. 1420/08, the Court of First Instance on Civil and Commercial Matters No. 12 of Rosario.

Eli Lilly and Company v Laboratorios Leti, S.A.V. y otra s/ Infracción de derechos (patente) (2011) Circunscripción Judicial of Caracas, Venezuela,Juzgado Superior Octavo en lo Civil, Mercantil, Tránsito y Bancario. [Judicial Circuit of Caracas, Venezuela, Eight High Tribunal on Civil, Commercial, Transit and Banking].

European Communities - Measures Affecting Asbestos and Asbestos-Containing Products: Appellate Body Report (WT/DS135/AB/R April 5 2001) 168.

F. Hoffmann-La Roche Ltd. and Anr. v Cipla Ltd 148 (2008) DLT 598, MIPR 2008 (2) 35.

Federal Republic of Nigeria $v$ Anache and 3 ors. (2004) 17 NSCQR 140

Freeman D.A.M., Lloyd's Introduction to Jurisprudence (9th edn, Sweet \& Maxwell 2014).

Gbemre v Shell Petroleum Development Company Nigeria Limited and Others, 152 (2005) AHRLR 151 (NgHC 2005).

General Sani Abacha \& 3 others v Gani Fawehinmi (2000) Volume 4 Federation Weekly Law Reports 533.

Helfer L.R., 'Toward a Human Rights Framework For Intellectual Property' (2007) 40972 University of California Davis Law review 971.

Helfer L.R., 'Human Rights and Intellectual Property: Conflict or Coexistence?' (2003) 5 Minnesota Intellectual Property Review 47.

Hunt P and Khosla R., 'The Human Right to Medicines' (2008) 5(8) Sur. Revista Internacional de Direitos Humanos 99.

International Convention on the Elimination of All Forms of Racial Discrimination 1965 Convention on the Rights of the Child adopted and opened for signature, ratification and accession by General Assembly resolution 44/25 of 20 November 1989.

International Covenant on Civil and Political Rights (ICCPR), Ratified October, 291993

Khandekar I, Tirpude BH and Murkey PN., 'Right to Health Care' (2012) 34 (2) Journal of Indian Academy of Forensic Medicine 160. 
Lawson C., 'Accessing and Affording Drugs Despite the Patent Barrier: Compulsory Licensing and Like Arrangements?' (2013) 24 AIPJ 94.

Lazzarini Z., 'Making Access to Pharmaceuticals a Reality: Legal Options under TRIPS and the Case of Brazil' (2003) 6(1) Yale Human Rights and Development Law Journal 103.

Maleche A and Day E, 'Right to Health Encompasses Right to Access Essential Generic Medicines: Challenging the 2008 Anti-Counterfeit Act in Kenya' (2014) 16(2) Health Human Rights 96.

Marzetti M., 'Comments on Ediciones De La Flor v Fontanarrosa Franco' (2013) 44(7) International Review of Industrial Property and Copyright Law

Media Rights Agenda and Others v Nigeria (2000) AHRLR 200 (ACHPR 1998) paragraphs 90.

Natco Pharma Ltd v Bayer Corporation Controller General of Patents, Mumbai, CLA No 1 of 2011. 35-61 (unreported)

Nigerian National Health Act 2014.

Nnamuchi O., 'Kleptocracy and its Many Faces: The Challenges of Justiciability of the Right to Health Care in Nigeria' (2008) 52 Journal of African Law 1.

Novartis AG v Union of India. IPAB Order No 100/2009

Nwabueze N.R., 'The Legal Protection and Enforcement of the Health Rights in Nigeria' in Colleen M Flood and Aeyal Gross (eds), The Right to Health at the Public/Private Divide: A Global Comparative Study (Cambridge University Press 2014)

Obilade A.O et al., (eds), Contemporary Issues in the Administration of Justice: Essay in Honour of Justice Atinuke Ige (Treasure Hall Konsult 2002)

Office of the United Nations High Commissioner for Human Rights and World Health Organization, The Right to Health: Fact Sheet No. 31 (Office of the United Nations High Commissioner for Human Rights and World Health Organization)

Ogudu v State (1994) 9 NWLR (Pt.366) 1

Okeke G.N., 'The Justiciability of the Non-Justiciable Constitutional Policy of Governance in Nigeria' (2013) 7 IOSR Journal of Humanities and Social Science 9.

Okere B., 'Fundamental Objectives and Directive Principles of State Policy under the Nigerian Constitution' (1983) 32 International and Comparative Law Quarterly 214.

Olafisoye v Federal Republic of Nigeria (2004) 4 NWLR (Pt. 864) 580.

Olowu D., An Integrative Rights-based Approach to Human Development in Africa (PULP 2009)

Optional Protocol to the Convention on the Rights of the Child on the involvement of Children in Armed Conflict.

Optional Protocol to the Convention on the Rights of the Child on the Sale of Children, Child Prostitution and Child Pornography.

Paschim Banga Khet Samity v State of West Bengal, Case No. 169, Judgement of 6 May 1996 Writ Petn. (Civil) No. 796 of 1992 (SC Agrawal, GT Nanavati JJ) (1996).

Patricia Asero Ochieng, Maurine Atieno, Joseph Munyi, and AIDS Law Project v Attorney General Petition No. 409 of 2009 (High Court of Kenya).

Peter Nemi v A. G of Lagos [1994]1LRC 376

Population Council, 'World Conference on Women: The Beijing Declaration and the Platform for Action on Women and Health' (1995) 21(4) Population and Development Review 910-911.

Preamble of the Constitution of the World Health Organization in UN General Assembly, Constitution of the World Health Organization (17 November 1947, A/RES/131).

Report of the Constitution Drafting Committee Vol 1 (Government Printer 1976).

SmithKline and French Laboratories Ltd v Netherlands Application 12633/87, (1990) ECHR

Social and Economic Rights Action Centre (SERAC) and another v Nigeria (2001) Communication No 155/96 African Commission on Human and Rights (ACHPR).

Socio-Economic Rights and Accountability Project (SERAP) v Federal Republic of Nigeria and Universal Basic Education Commission (2012) No. ECW/CCJ/APP/0808.

Sood M, 'Natco Pharma Ltd. V. Bayer Corporation and the Compulsory Licensing Regime in India' [2013] NUJS Law Review, 104.

Soohoo C and Goldberg J., 'The Full Realization of Our Rights: The Right to Health in State Constitutions' (2010) 60(4) Case Western Reserve Law Review 997.

Sun H., 'A Wider Access to Patented Drugs under the TRIPS Agreement' (2003) 21 Boston University International Law Journal 101.

'Supreme Court Says No to Bayer, Upholds Compulsory License on Nexavar' (Lawyerscollective.org)

The Beijing Declaration and Platform of Action was adopted at the Fourth World Conference on Women, convened by the UN in Beijing, China, in 1995.

The Convention Against Torture and Other Cruel, Inhuman or Degrading Treatment or Punishment (CAT) 
Ratified July 28, 2001

The Convention on the Elimination of All Forms of Discrimination Against Women (CEDAW) Ratified July 13, 1985

The Convention on the Rights of the Child (CRC) Ratified April 19, 1991.

The International Convention on the Elimination of All Forms of Racial Discrimination (the ICERD) Ratified January 4, 1969

The International Covenant on Economic, Social and Cultural Rights (ICESCR), Ratified October 29, 1993.

Thirteenth Annual Activity Report of the African Commission on Human and Peoples' Rights 1999 - 2000.

U Umozuruike The African Charter on Human and Peoples' Rights (Kluwer Law International 1997)

UN Committee on Economic, Social and Cultural Rights (CESCR), General Comment No 14: The Right to the Highest Attainable Standard of Health (Article 12 of the Covenant) (Adopted at the Twenty-second Session of the Committee on Economic, Social and Cultural Rights, on 11 August 2000 E/C.12/2000/4)

UN General Assembly, Convention on the Elimination of All Forms of Discrimination Against Women (Adopted 18 December 1979, entry into force 3 September 1981 UNTS 1249, 13).

UN Women, Beijing Declaration and Platform for Action: Beijing +5 Political Declaration and Outcome (UN Women 2014).

United Nations General Assembly, International Covenant on Economic, Social and Cultural Rights (Adopted 16 December 1966, entry into force 3 January 1976, United Nations Treaty Series volume 993, 3)

Uwais L.M., 'Fundamental Objectives and Directive Principles of State Policy: Possibility and Prospect' in CC Nweze (ed), Justice in the Judicial Process: Essay in Honour of Honourable Justice Eugene Uba Ubaezonu (Fourth Dimension Publishing Company 2002)

Uzoukwu v Ezeonu (1991) 6 NWLR (pt 2000) 761.

Vadi V., Public Health in International Investment Law and Arbitration (Routledge 2012). 